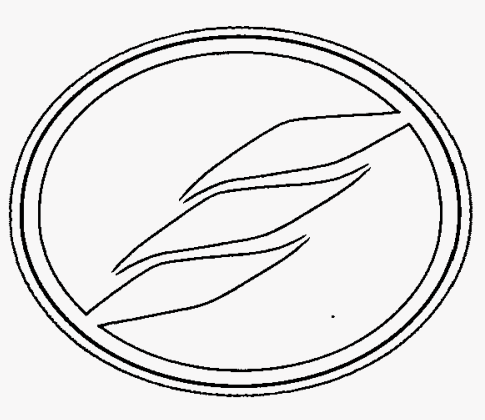

INEEY/EXT-98-01107

November 1998

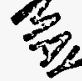

然<smiles>[CH-]</smiles>

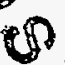

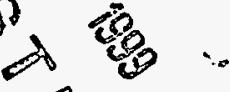

Interim Status of the

Accelerated Site

Technology Deployment

Integrated Decontamination and Decommissioning

Project
A. M. Smith
G. E. Matthern
R. H. Meservey

LOCKHEED MARTIN 


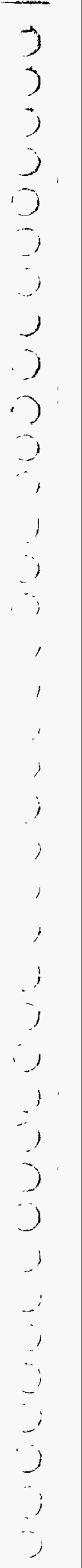

United States Government. Neither the United States Government nor any agency thereof, nor any of their employees, makes any warranty, express or implied, or assumes any legal liability or responsibility for the accuracy, completeness, or usefulness of any information, apparatus, product or process disclosed, or represents that its use would not infringe privately owned rights. References herein to any specific commercial product, process, or service by trade name, trademark, manufacturer, or othenwise, does not necessarily constitute or imply its endorsement, recommendation, or favoring by the United States Government or any agency thereof. The views and opinions of authors expressed herein do not necessarily state or reflect those of the United States Government or any agency thereof. 


\section{DISCLAIMER}

Portions of this document may be illegible in electronic image products. Images are produced from the best available original document. 


\title{
Interim Status of the Accelerated Site Technology Deployment Integrated Decontamination and Decommissioning Project
}

\author{
A. M. Smith \\ G. E. Matthern \\ R. H. Meservey
}

Published November 1998

Idaho National Engineering and Environmental Laboratory Environmental Restoration Technology Department Lockheed Martin Idaho Technologies Company Idaho Falls, Idaho 83415

Prepared for the U.S. Department of Energy Office of Environmental Management Under DOE Idaho Operations Office Contract DE-AC07-94ID13223 


\section{SUMMARY}

The U.S. Department of Energy complex has many surplus facilities highly contaminated with various radioactive and hazardous substances. Many of these facilities need to be decontaminated and decommissioned to free them for other uses and to reduce the number of facilities requiring maintenance and surveillance. The baseline methods for decontaminating and decommissioning these facilities are sometimes costly, time consuming, and create high levels of radiation exposure. Although improved technologies exist and have been demonstrated in the large-scale technology demonstrations, they have not become widely accepted and used in D\&D operations.

The Idaho National Engineering and Environmental Laboratory (INEEL), Fernald Environmental Management Project (FEMP), and Argonne National Laboratory - East (ANL-E) teamed to establish the Accelerated Site Technology Deployment (ASTD) Integrated Decontamination and Decommissioning (ID\&D) project to increase the use of improved technologies in D\&D operations. The project is making the technologies more readily available, providing training, putting the technologies to use, and spreading information about improved performance.

The improved technologies are expected to reduce cost, schedule, radiation exposure, or waste volume over currently used baseline methods. They include some of the most successful technologies proven in the large-scale demonstrations and in private industry. The selected technologies are the Pipe Explorer, the GammaCam, the Decontamination Decommissioning and Remediation Optimal Planning System (DDROPS), the BROKK Demolition Robot, the Personal Ice Cooling System (PICS), the Oxy-Gasoline Torch, the Track-Mounted Shear, and the Hand-Held Shear.

The ASTD ID\&D project received funding in February 1998. During the remainder of FY-98, technology selection was confirmed, procurement of technologies was completed, deployment activities were begun, and the inter-site team was strengthened. The technologies procured are the Oxy-Gasoline Torch, Personal Ice Cooling System, Track-Mounted Shear, and BROKK Demolition Robot with four end-effectors. In addition, a contamination control enclosure for the GammaCam was built and a subcontract for the Pipe Explorer was issued. Deployment of the Oxy-Gasoline Torch, Track-Mounted Shear, Personal Ice Cooling System, and Hand-Held Shear aided in decommissioning five facilities. INEEL and FEMP formed a strong team. ANL-E has also participated in the team and will be taking a more active role in FY-99 as their work develops. 


\section{ACKNOWLEDGMENTS}

We acknowledge the significant roles played by Paul Hart, Harold Shoemaker, Jim Wade, and Chelsea Hubbard of the U.S. Department of Energy in providing programmatic guidance and support for this project.

We acknowledge the ASTD ID\&D team members of FEMP and ANL-E for their significant contributions to the success of the project.

We also acknowledge the help received from the suppliers of the deployment equipment, INEEL D\&D Operations, and the INEEL ID\&D team. 


\section{CONTENTS}

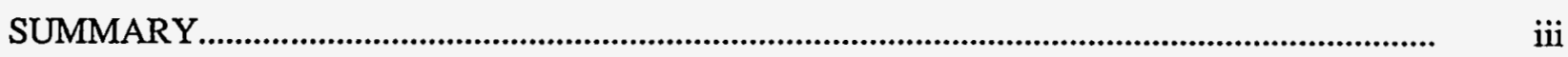

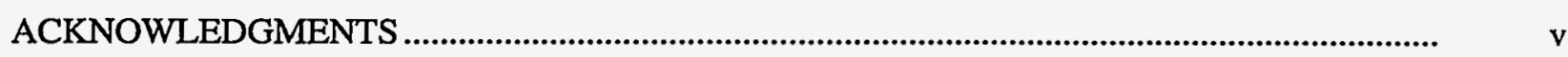

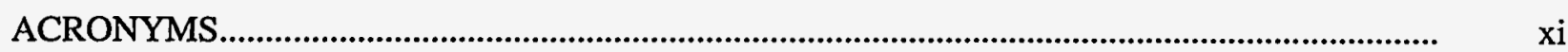

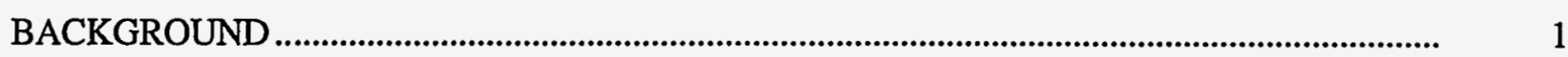

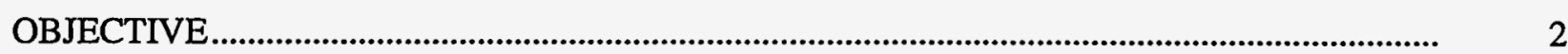

DECONTAMINATION AND DESCOMMISSIONING NEEDS ................................................. 3

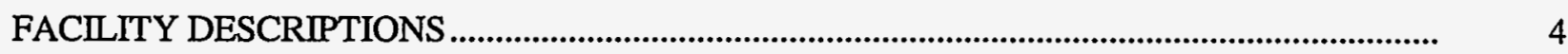

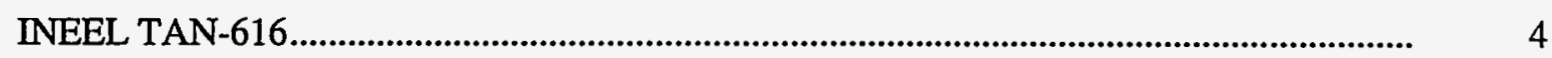

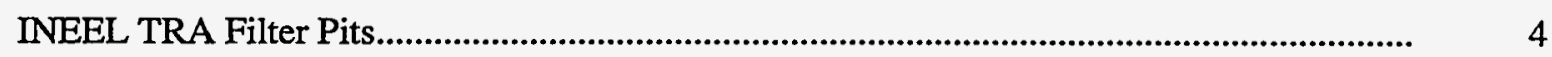

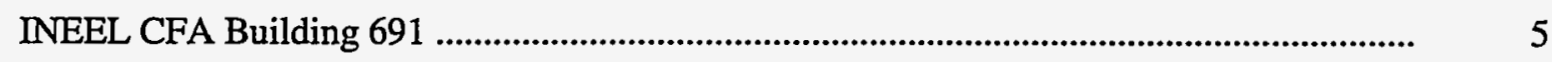

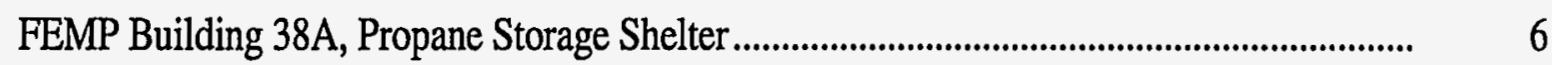

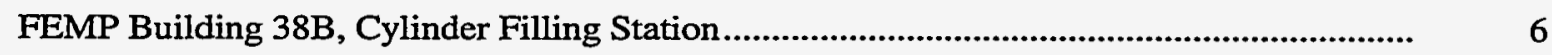

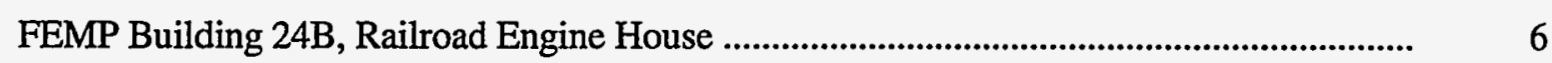

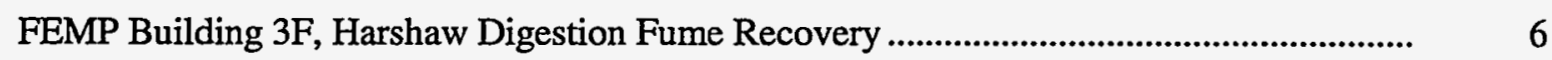

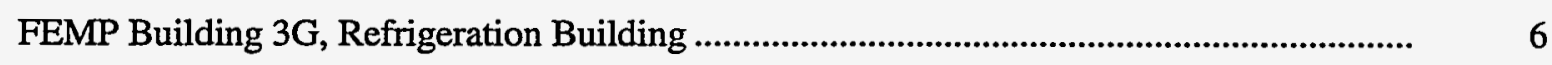

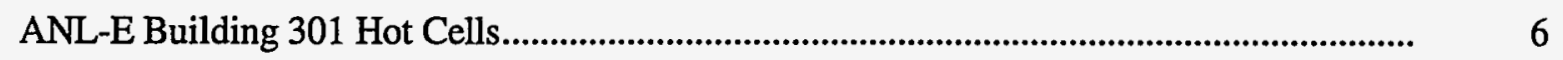

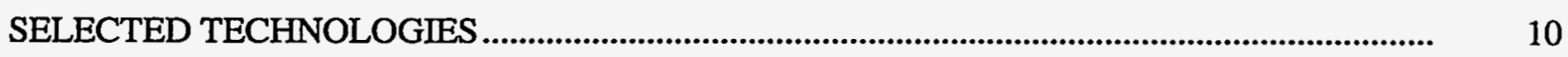

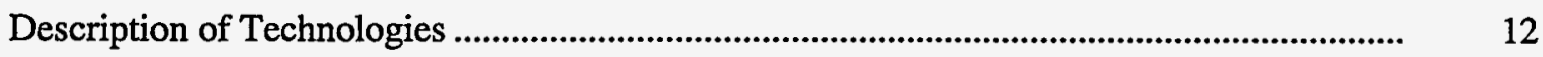

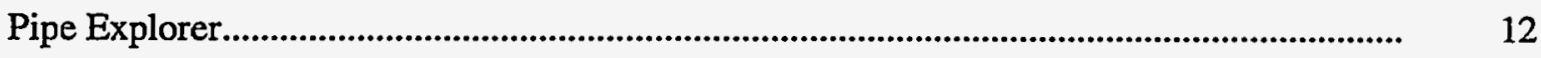

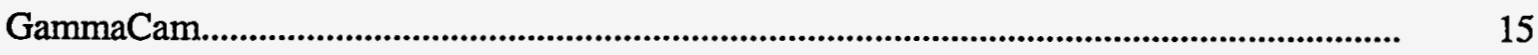

The D\&D and Remediation Optimal Planning System (DDROPS) .................................. 16

BROKK Demolition Robot with Hammer, Hydraulic Shear, Grapple, and Scabbler ............ 17

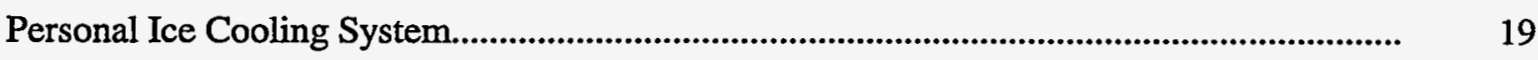

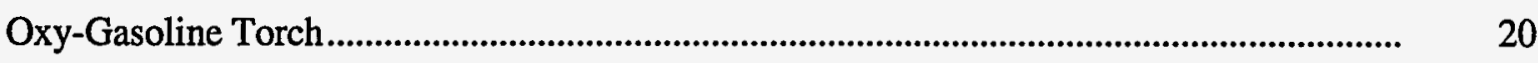

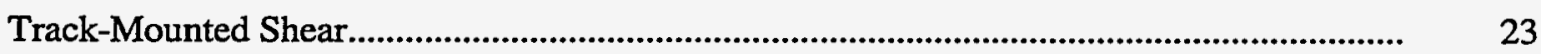




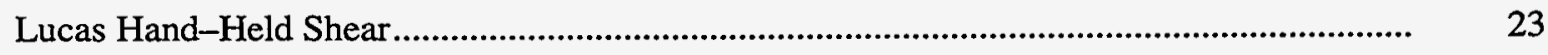

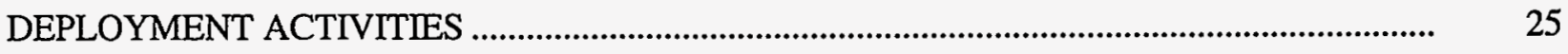

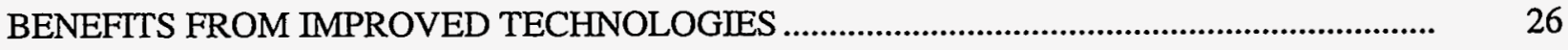

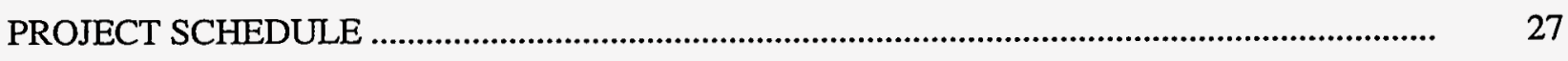

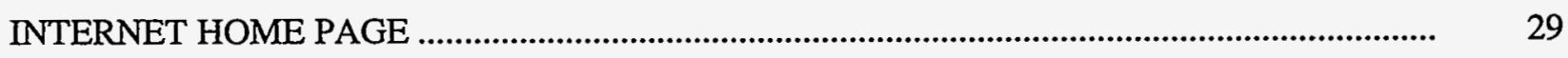

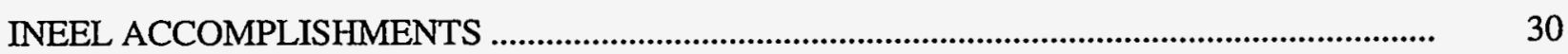

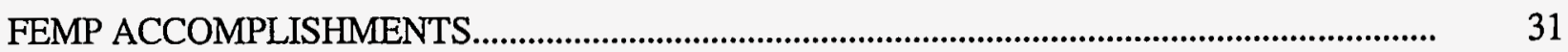

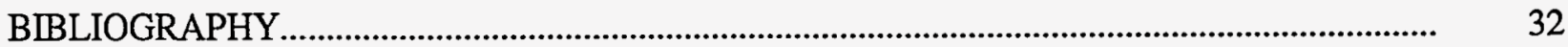

Appendix A-Communications Plan for the Integrated Decontamination and Decommissioning

Project in the Accelerated Site Technology Deployment Program

\section{FIGURES}

1. D\&D of INEEL's Liquid Waste Processing Facility, TAN-616, will be aided by using

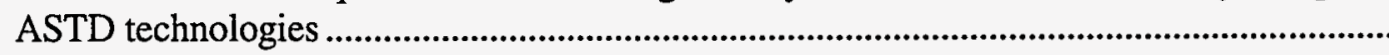

2. D\&D of the INEEL CFA Sewage Treatment Plan (CFA-691) will use the Oxy-Gasoline Torch and the BROKK Demolition Robot with scabbler. .................................................... 5

3. FEMP Building 38A, Propane Storage Shelter, before demolition ...................................... 7

4. Using ASTD technologies, the FEMP Propane Storage Building was demolished in FY-98

5. The Hand-Held Shear, Oxy-Gasoline Torch, and Truck-Mounted Shear were all deployed during decontamination and decommissioning the Railroad Engine House, Building 24B at FEMP.

6. Through the ASTD Program, the Harshaw Tower, FEMP Building 3F, was decontaminated and decommissioned to make way for remediation of the nearby Hazardous Waste Management Unit.

7. Through the ASTD Program, FEMP Building 3G, the Refrigeration Building, was decontaminated and decommissioned in FY-98

8. The Pipe Explorer will characterize piping at the INEEL TRA Filter Pits ........................... 12

9. The Pipe Explorer remotely characterizes piping, offering visual and radiation data ............ 13

10. A protective membrane keeps the sensor clean during Pipe Explorer deployment ................ 14 
11. The GammaCam performs remote radiation surveys, reducing worker radiation exposure

12. The GammCam is controlled remotely by a notebook computer

13. The BROKK 250 Demolition Robot uses a variety of end effectors to perform remote D\&D operations

14. When operating the BROKK scabbler remotely, workers receive less radiation exposure than they would during hand-held scabbling operations.

15. The Personal Ice Cool System keeps workers cool, extending stay times and increasing productivity

16. The Oxy-Gasoline Torch reduces cost because it cuts significantly faster than baseline methods and uses a much less expensive fuel.

17. Backflash is prevented in the Oxy-Gasoline Torch because the gasoline is liquid all the way to the mixing tip.

18. The Track-Mounted Shear reduced cost and exposure during D\&D operations at FEMP.....

19. Using the Hand-Held Shears reduces exposure to airborne lead sawing and grinding operations

\section{TABLES}

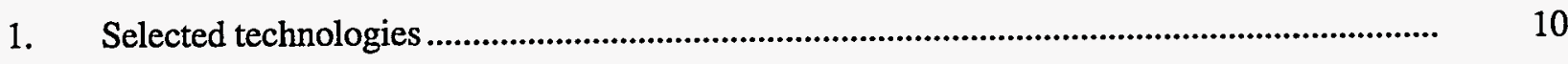

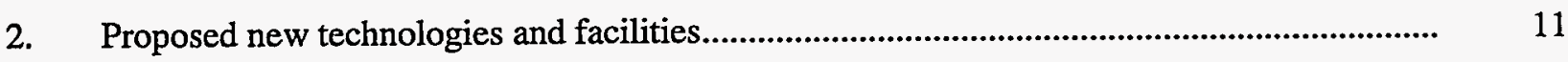

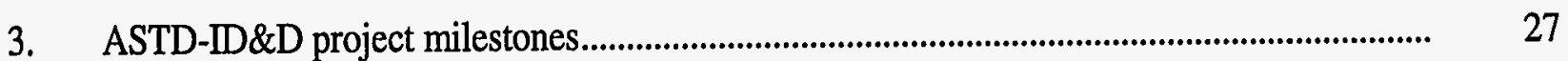

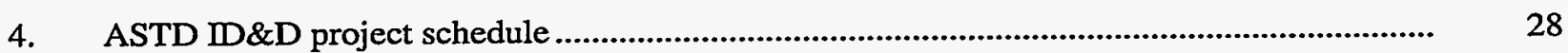

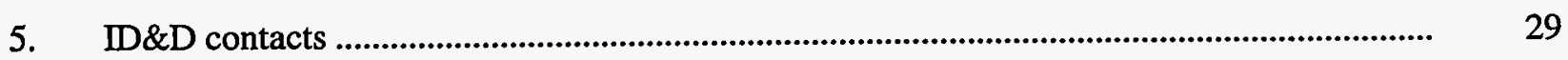

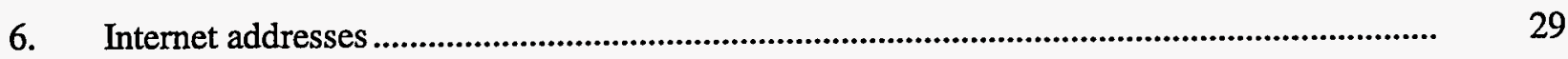




\section{ACRONYMS}

ACM asbestos containing material

ASTD accelerated site technology deployment

ANL-E Argonne National Laboratory-East

CFA Central Facilities Area

D\&D decontamination and decommissioning

DDROPS Decontamination, Decommissioning, and Remediation Optimal Planning System

DOE Department of Energy

EM Environmental Management

EM-40 DOE Office Environmental Restoration

ETR Engineering Test Reactor

FEMP Fernald Environmental Management Project

FIU Florida International University

HEPA high-efficiency particulate air

ICT Integrated Contractor Team

ID\&D Integrated Decontamination and Decommissioning

IET Initial Engine Test

INEEL Idaho National Engineering and Environmental Laboratory

LSTD Large-Scale Technology Demonstration Program

PICS Personal Ice Cooling System

PTS Project Tracking System

STCG Site Technology Coordination Group

STP Sewage Treatment Plant

TRA Test Reactor Area

TTP Technical Task Plan 


\title{
Interim Status of the Accelerated Site Technology Deployment Integrated Decontamination and Decommissioning Project
}

\author{
BACKGROUND
}

The U.S. Department of Energy (DOE) sites contain many highly contaminated surplus facilities that need to be decontaminated and decommissioned. The facilities include a large range of construction types but, have common decontamination and decommissioning (D\&D) problems. Under the Accelerated Site Technology Deployment (ASTD) Project, improved technologies will be used to D\&D representative facilities, resulting in benefits in cost, schedule, radiation exposure, waste volume, and safety.

DOE facilities include several construction types. They range from concrete block to structural steel to massive cast-in-place, steel-reinforced concrete and contain large amounts of steel piping and equipment. They are highly contaminated with various radioactive and hazardous substances that require special handling or restrictions for human exposure.

The Idaho National Engineering and Environmental Laboratory (INEEL), Fernald Environmental Management Project (FEMP), and Argonne National Laboratory-East (ANL-E) teamed to identify key facilities at each site that represent the construction types and major challenges for D\&D projects across the DOE complex. The ASTD Project will use improved technologies to D\&D these buildings. Deploying the improved technologies will accelerate D\&D schedules, reduce overall cost, reduce worker exposure to radioactive and hazardous environments, reduce the volume of waste disposed, and improve safety. 


\section{OBJECTIVE}

The overall objective of the Accelerated Site Technology Deployment (ASTD) Integrated Decontamination and Decommissioning (ID\&D) project is to increase the use of innovative but proven technologies on a large scale in the D\&D of facilities in the Department of Energy (DOE) complex. The reason for increasing the use of these innovative technologies is that each has demonstrated improvements over current baseline methods in cost, schedule, waste generation, radiation exposure, or safety. Increased use on a large scale will be accomplished by doing actual D\&D projects with the selected innovative technologies, thereby increasing user familiarity and experience with them and adding them to the array of tools available for D\&D projects. The technologies added to the D\&D toolbox have all been proven on a smaller scale, either through demonstration in large-scale technology demonstration (LSTD) projects or through commercial use, but they have not been used to decontaminate and decommission facilities across the DOE complex. After completing the project, DOE hopes to see increased use of these technologies that will result in ongoing cost savings at the three participating sites and other sites in the DOE complex. 


\section{DECONTAMINATION AND DESCOMMISSIONING NEEDS}

Facilities selected for this deployment project present problems typical of decommissioning nuclear facilities throughout the DOE Complex and private industry. Some typical problems associated with facilities follow:

- Unknown location of high-intensity radiation or hot spots

- Unknown location of underground pipes servicing the facility

- Large volume of waste materials

- High levels of radiation resulting in short stay times for workers

- Large amounts of contaminated concrete

- Loose, highly radioactive contamination on surfaces and equipment inside the buildings

- Large metal structures and equipment that need to be reduced in size for removal

- Massive high-density concrete structures

- $\quad$ High temperatures for workers.

Facilities with some of these problems were selected at INEEL, FEMP, and ANL-E. FEMP completed decontamination and decommissioning of five buildings in Fiscal Year 1998 (FY-98). During FY-99, two buildings at INEEL and one hot cell at ANL-E will be decontaminated and decommissioned. FEMP plans to deploy the ASTD technologies at numerous facilities in FY-99 as part of normal operations. 


\section{FACILITY DESCRIPTIONS}

Suitable facilities have been identified at INEEL, FEMP, and ANL-E. A brief description of each facility selected to initially deploy the improved D\&D technologies follows.

\section{INEEL TAN-616}

This liquid waste treatment facility (see Figure 1) was constructed in 1958 and consists of a stainless steel evaporator that collected off-gas condensation and evaporator bottoms. It operated for 12 years until its highly contaminated condition prevented proper repair of increasingly frequent malfunctions. The relatively small structure has exterior dimensions of $11 \mathrm{~m} \times 14 \mathrm{~m}(36 \times 46 \mathrm{ft})$ and is $7 \mathrm{~m}$ (23-ft) tall. It contains several rooms, a basement, an evaporator, numerous pumps and tanks, and miscellaneous equipment. Everything within the building is highly contaminated, and the contamination becomes airborne easily. This facility is typical within the DOE Complex.

\section{INEEL TRA Filter Pits}

The Test Reactor Area (TRA) Engineering Test Reactor (ETR), completed in 1957 and inactive since December of 1981, include facilities that tested gas-cooled systems. Activated charcoal filters and delay tanks (all below grade) connected by a network of pipes, tunnels, and trenches were used to process exhaust gases. The three filters under TRA building 755 were at first connected by asbestos-insulated piping from the ETR basement through a tunnel $2.3-\mathrm{m}(7.5-\mathrm{ft})$ high and $2-\mathrm{m}(6.5-\mathrm{ft})$ wide running north

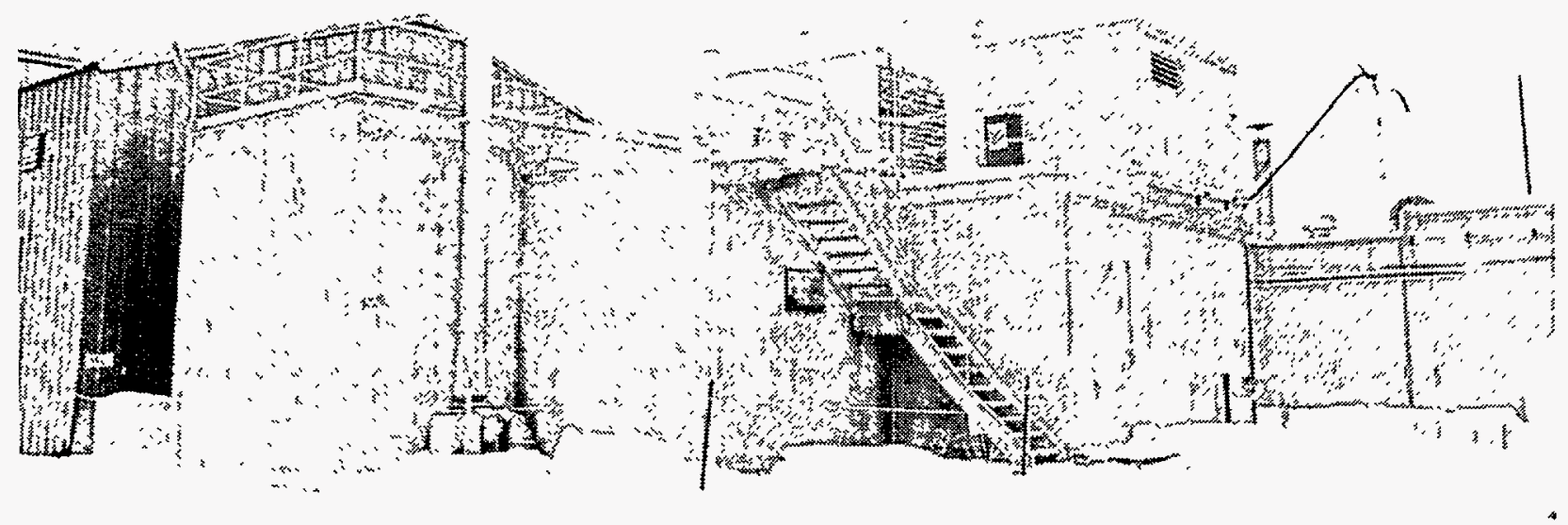

Figure 1. D\&D of INEEL's Liquid Waste Processing Facility, TAN-616, will be aided by using ASTD technologies. 
for $27.4 \mathrm{~m}(90 \mathrm{ft})$ then east for $47 \mathrm{~m}(155 \mathrm{ft})$ at $2.7-\mathrm{m}(9-\mathrm{ft})$ belowgrade. In 1960, two more filter pits (primary and secondary), and two delay tanks were added with pipe trenches running parallel to the

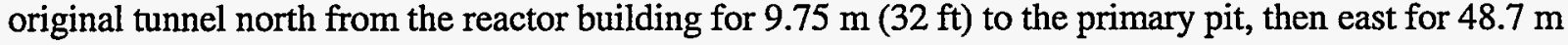
( $160 \mathrm{ft}$ ) to the secondary pit near building 755 , then continuing east another $19.8 \mathrm{~m}(65 \mathrm{ft})$ to the delay tanks pit. The trenches are half-round corrugated plate anchored on a concrete base and vary from 1.4 to $1.7-\mathrm{m}$ ( 4.5 to $5.5-\mathrm{ft}$ ) wide by 1 to $1.14-\mathrm{m}$ ( 3 to $3.75-\mathrm{ft}$ ) high lying 4.3 to $4.9-\mathrm{m}$ ( 14 to $16-\mathrm{ft}$ ) belowgrade.

\section{INEEL CFA Building 691}

The Central Facilities Area (CFA) Sewage Treatment Plant (STP) (see Figure 2) pumphouse, building 691, is a two-story solid-concrete building with an exterior area of about $63.5 \mathrm{~m}^{2}\left(684 \mathrm{ft}^{2}\right)$. The

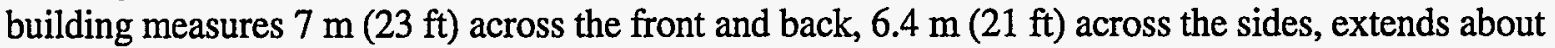

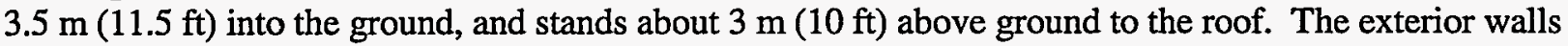
and floor are concrete, and the roof is reinforced concrete. The building has three interconnected hatches: a west wall hatch, west pump port, and east pump port. The pumphouse basement contains three pumps that were used to pump raw sewage from the holding tank. There is an estimated $0.9 \mathrm{~m}^{3}\left(32 \mathrm{ft}^{3}\right)$ of sludge in the building, about $0.3 \mathrm{~m}^{3}\left(10 \mathrm{ft}^{3}\right)$ of potentially contaminated water in the basement, and $15.7 \mathrm{~m}^{3}$ $\left(554 \mathrm{ft}^{3}\right)$ of potentially contaminated water in the deep well area. The roof has about $29.7 \mathrm{~m}^{2}\left(320 \mathrm{ft}^{2}\right)$ of asbestos containing material (ACM). There are $28 \mathrm{~m}$ (92 linear feet) of asbestos pipe lagging, and the roof pipe vents have about $0.14 \mathrm{~m}^{3}\left(5 \mathrm{ft}^{3}\right)$ of lead flashing.

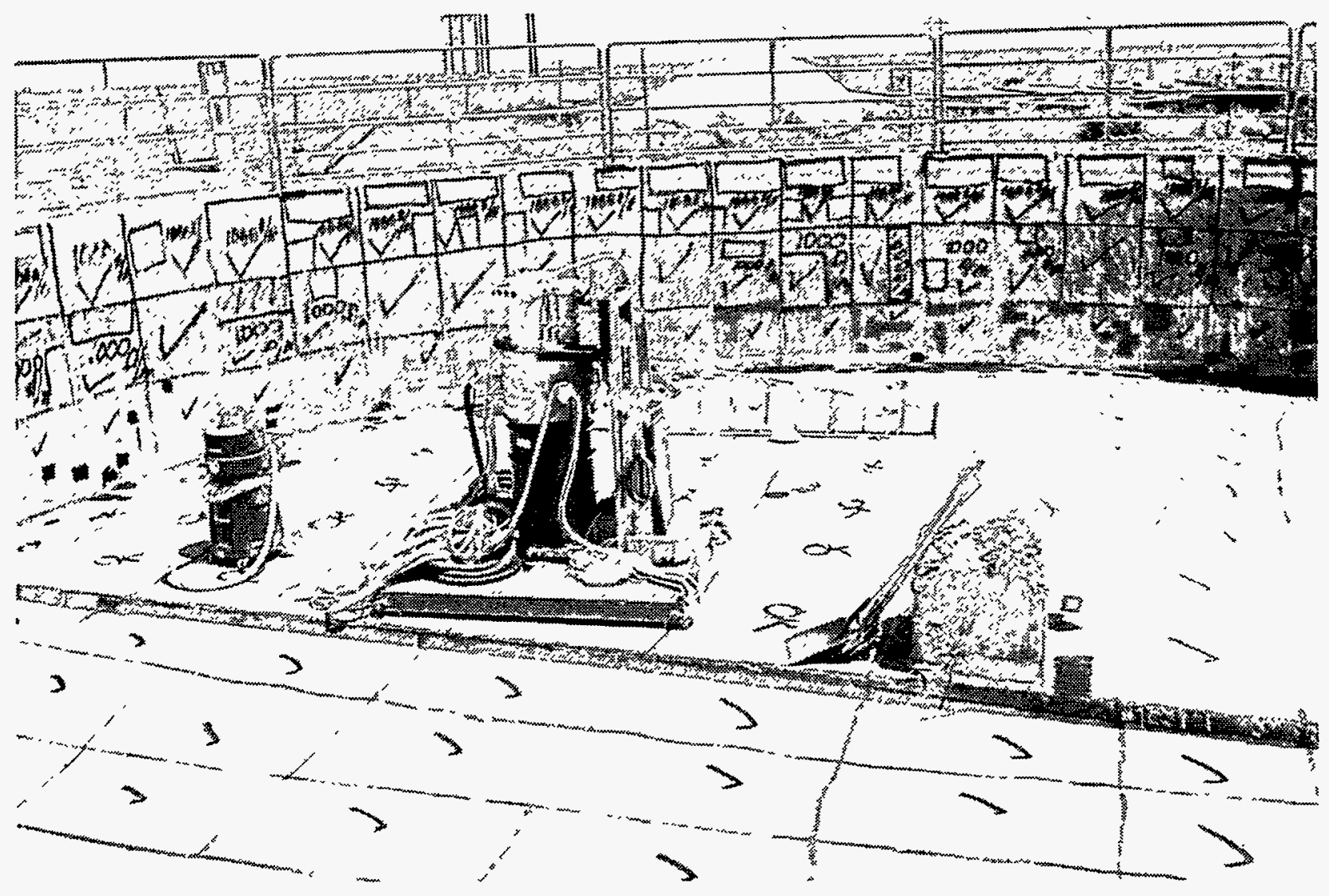

Figure 2. D\&D of the INEEL CFA Sewage Treatment Plan (CFA-691) will use the Oxy-Gasoline Torch and the BROKK Demolition Robot with scabbler. 


\section{FEMP Building 38A, Propane Storage Shelter}

This building is a single-story structure consisting of a cement block wall and reinforced concrete floor and contains two propane storage tanks (see Figures 3 and 4). The building houses monitoring and vaporization equipment for propane. A radiological survey showed values for removable beta-gamma averaged 60 disintegrations per minute $(\mathrm{dpm})$ with a maximum value of $389 \mathrm{dpm}$. The average total beta-gamma reading was $2,284 \mathrm{dpm}$; the hot spot was recorded at $30,000 \mathrm{dpm}$. The removable alpha levels exhibited an average of $28 \mathrm{dpm}$ and a maximum of $119 \mathrm{dpm}$.

\section{FEMP Building 38B, Cylinder Filling Station}

This building is single story, consisting of a steel frame and reinforced concrete floor. The building was used to fill pressurized steel cylinders with propane.

\section{FEMP Building 24B, Railroad Engine House}

Building 24B (see Figure 5) provided covered storage and undercarriage maintenance access for a railroad locomotive. The $8.3 \times 26 \mathrm{~m}(27 \times 85 \mathrm{ft})$ building is cement block with reinforced poured concrete footers and floor, glass windows, and a flat reinforced poured concrete roof over a single level 4.9-m (16-ft) high. Contaminants include ethylene glycol and lubricating oil.

\section{FEMP Building 3F, Harshaw Digestion Fume Recovery}

Building 3F (see Figure 6) was used for Harshaw fume recovery to relieve the fume load of the Nitric Acid Recovery facility. Nitrogen oxide fumes from the metal dissolver and digestion were collected to produce nitric acid. The $5.8 \times 12.2-\mathrm{m}(19 \times 40-\mathrm{ft})$ open steel structure is $10.7-\mathrm{m}(35-\mathrm{ft})$ high and contains absorber towers and tanks.

\section{FEMP Building 3G, Refrigeration Building}

This is a transite building measuring approximately $4.9 \times 13.4 \mathrm{~m}(16 \times 44 \mathrm{ft})$ and $3.35-\mathrm{m}(11-\mathrm{ft})$ high, with a concrete floor and a transite roof (see Figure 7). It originally housed equipment that provided cooling support for the Harshaw nitric acid recovery process. After that equipment was removed, it housed an instrument repair shop, and it is now used to store sampling equipment and supplies. During radiological surveys performed from 1989 to 1992, 162 removable alpha measurements were performed, with an average value of $167 \mathrm{dpm}$. Beta-gamma surveys were conducted in 1991 . Nineteen total betagamma measurements were performed, with an average of 55,080 dpm and a highest measurement of $900,000 \mathrm{dpm}$.

\section{ANL-E Building 301 Hot Cells}

Building 301 was one of the first occupied permanent buildings at the Argonne National Laboratory site. It is approximately $36.6 \times 27.4 \mathrm{~m}(120 \times 90 \mathrm{ft})$ with a basement service floor, a main floor containing 7 hot cells and laboratory space, and a second floor with offices. There is also a subbasement with retention tanks for radioactive liquid storage and a second-story penthouse housing the HEPA filtration systems.

The main floor containing the hot cells is significantly contaminated with mixed fission products and transuranics from past operations. Most of the contamination exterior to the cells has been painted over and tightly adheres to the building surfaces. The cells themselves are of early vintage high-density concrete construction containing significant amounts of lead shielding. In addition to the radioactive contamination, there are significant quantities of asbestos, lead-based paint, and other potentially hazardous materials. 


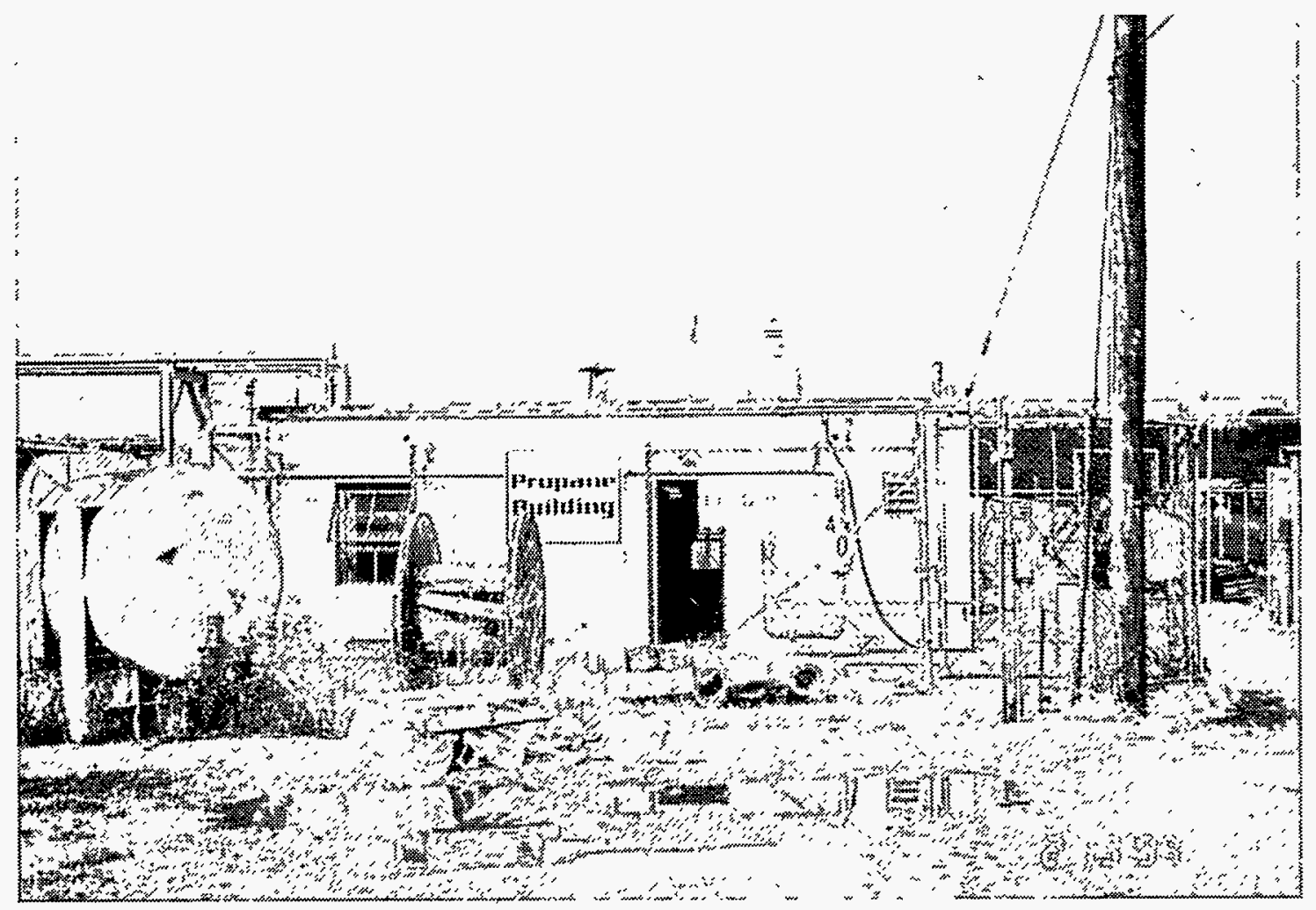

Figure 3. FEMP Building 38A, Propane Storage Shelter, before demolition.

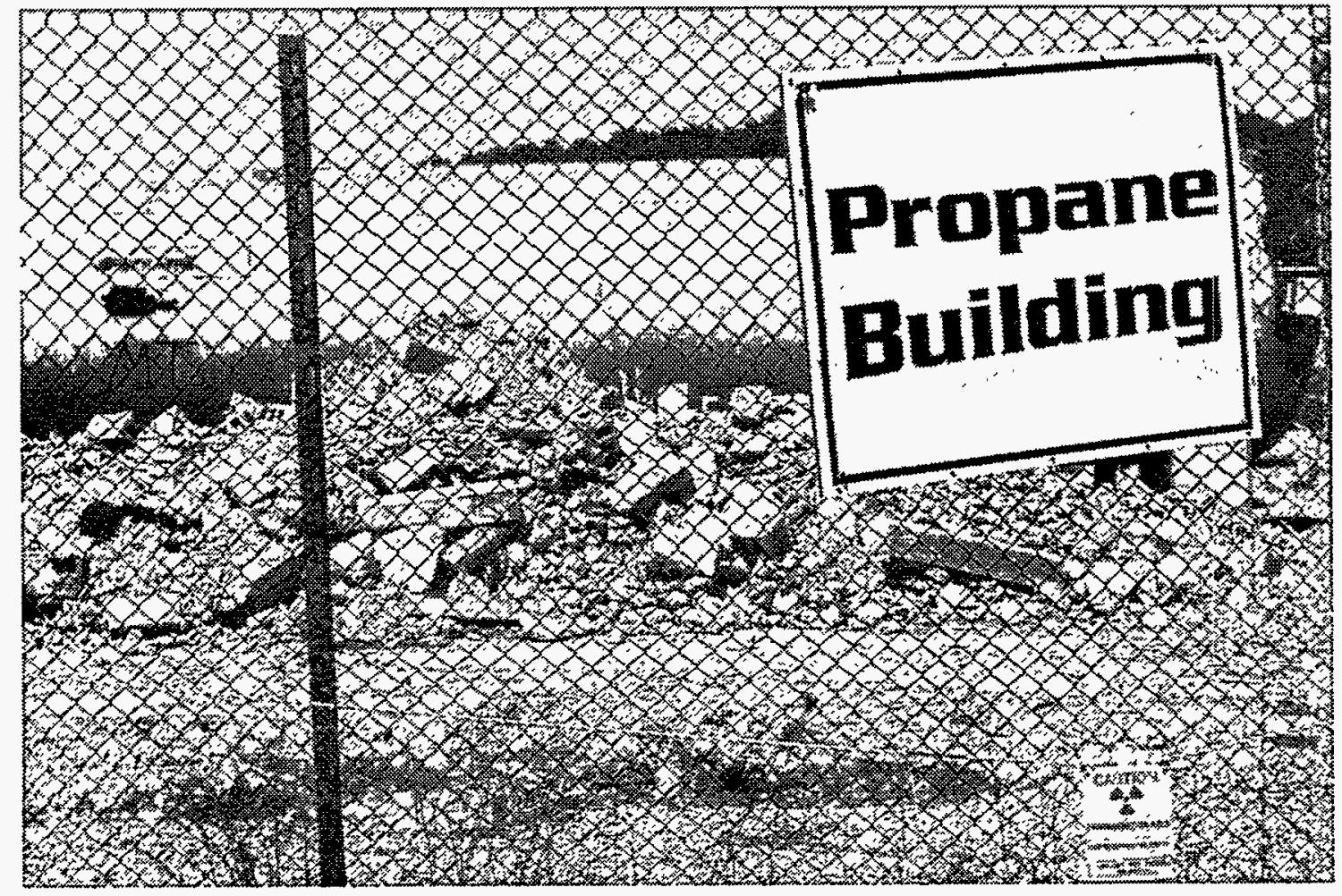

Figure 4. Using ASTD technologies, the FEMP Propane Storage Building was demolished in FY-98. 


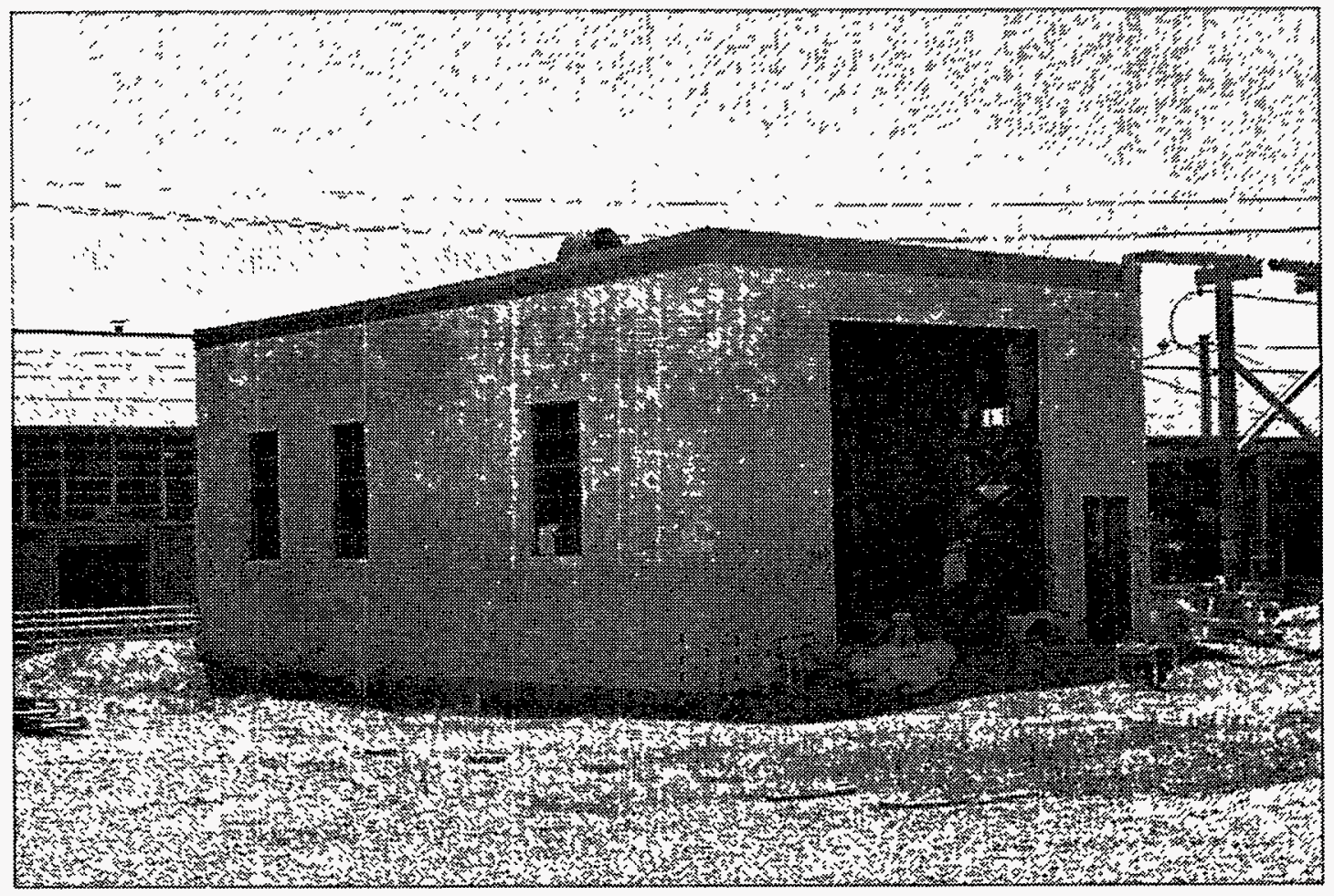

Figure 5. The Hand-Held Shear, Oxy-Gasoline Torch, and Truck-Mounted Shear were all deployed during decontamination and decommissioning the Railroad Engine House, Building 24B at FEMP.

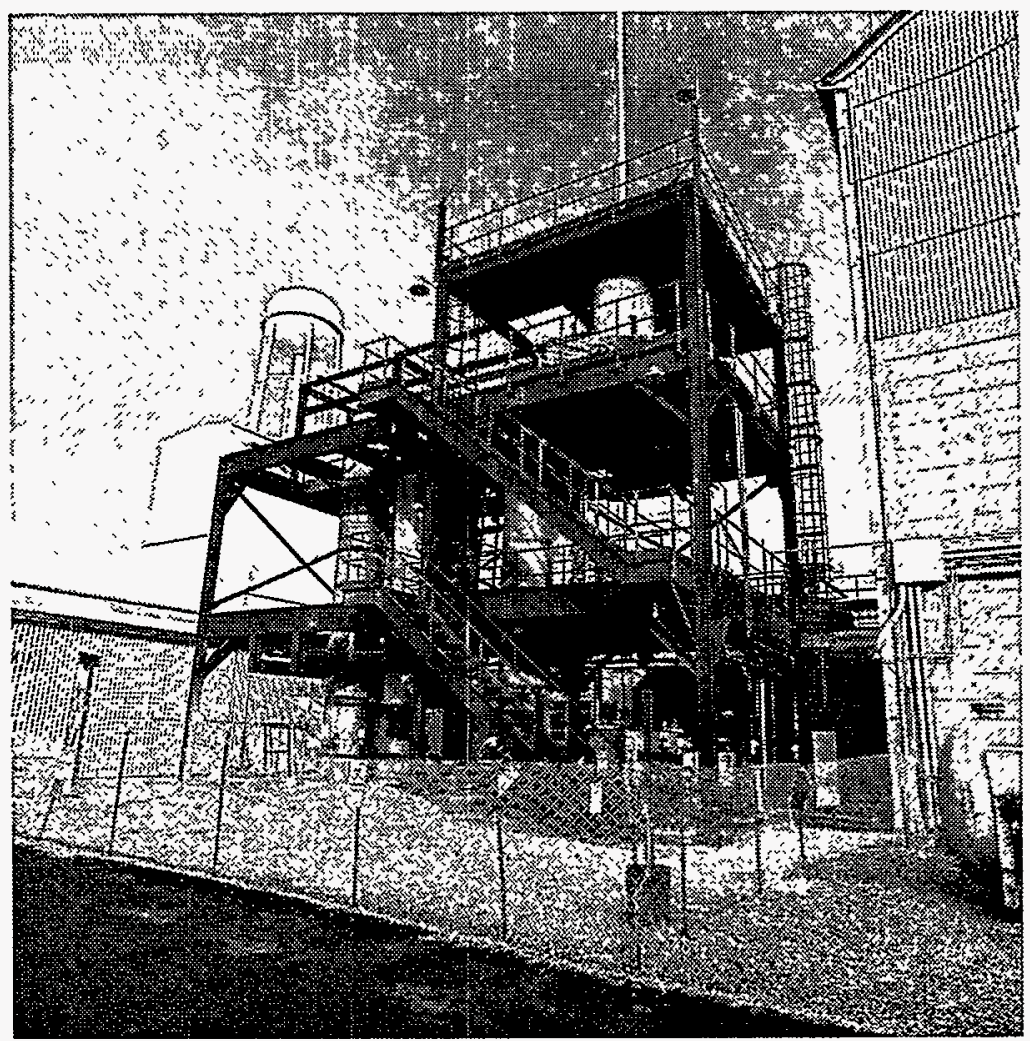

Figure 6. Through the ASTD Program, the Harshaw Tower, FEMP Building 3F, was decontaminated and decommissioned to make way for remediation of the nearby Hazardous Waste Management Unit. 


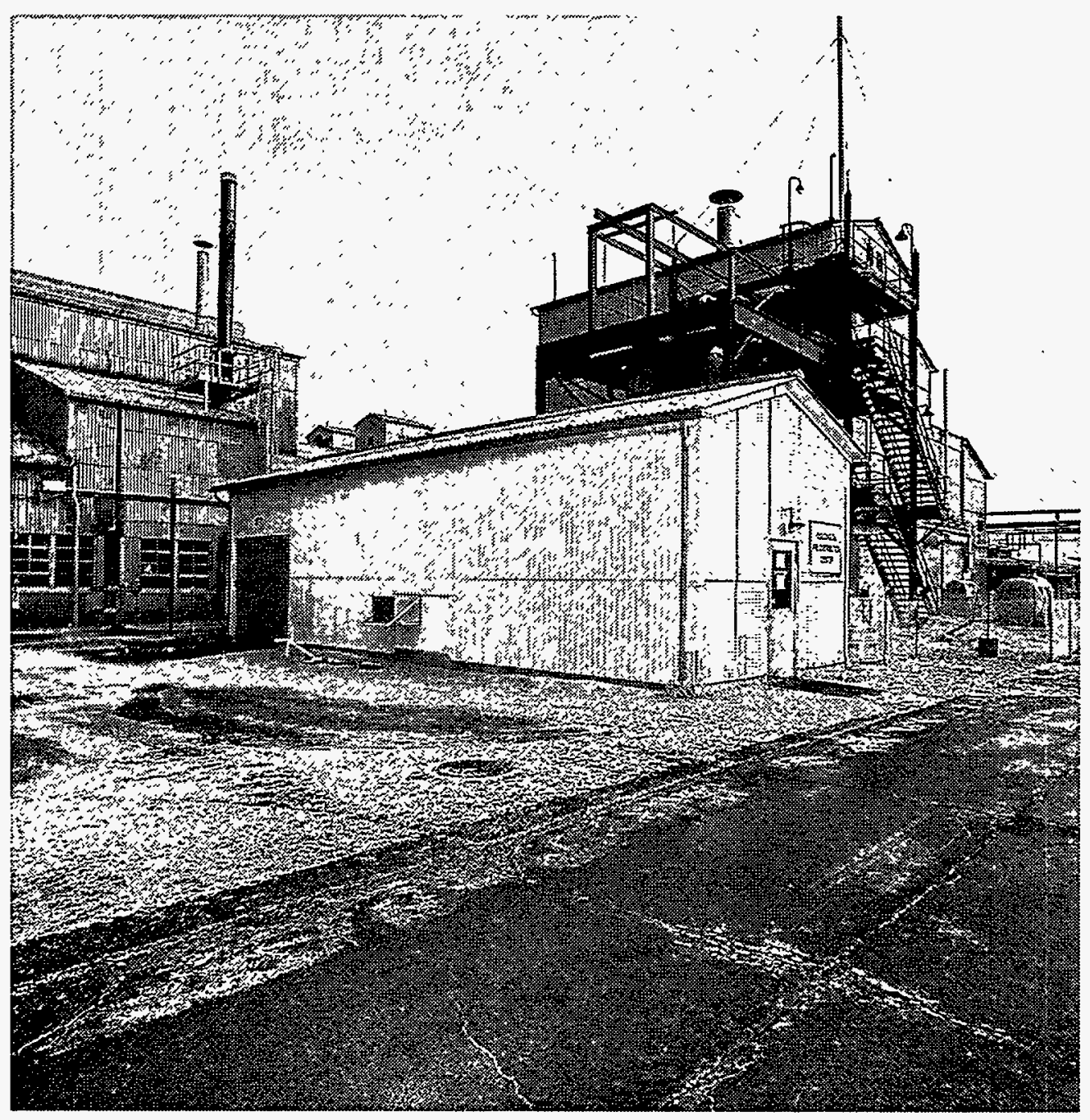

Figure 7. Through the ASTD Program, FEMP Building 3G, the Refrigeration Building, was decontaminated and decommissioned in FY-98. 


\section{SELECTED TECHNOLOGIES}

The selected technologies (see Table 1) will demonstrate improved performance over the baseline technologies for this series of D\&D projects. The technologies have each been used either in one of the large-scale D\&D technology demonstration projects or at other decommissioning projects within DOE or private industry. The strength of these technologies is that they are the best of the improved technologies demonstrated and will be applied to the appropriate problems at the selected D\&D facilities (see Table 2). Because they have been used for many years, the performance specifications for the baseline technologies are documented and well known. They are documented in such publications as the Decommissioning Handbook (DOE/EM-0142P, March 1994), in the new D\&D Technology Module, Beta Test Version, and in the many reports associated with the $D \& D$ of nuclear facilities that have been completed to date.

Table 1. Selected technologies.

\begin{tabular}{|c|c|c|c|}
\hline Technology & Function & $\begin{array}{c}\text { Deployment } \\
\text { Site }\end{array}$ & Supplier \\
\hline Pipe Explorer & $\begin{array}{l}\text { Remote visual } \\
\text { inspection and } \\
\text { gamma logging of } \\
\text { piping }\end{array}$ & INEEL & $\begin{array}{l}\text { Science and Engineering Associates, } 6100 \\
\text { Uptown Blvd. N.E., Suite 700, Albuquerque, } \\
\text { NM } 87110 \\
\text { David Cremer, 505-884-2300, } \\
\text { cdcremer@seabase.com }\end{array}$ \\
\hline GammaCam & $\begin{array}{l}\text { Thorough and } \\
\text { documented remote } \\
\text { radiation survey }\end{array}$ & INEEL & $\begin{array}{l}\text { AIl Systems, } 455 \text { Commack Road, Deer Park, } \\
\text { NY } 11729 \\
\text { Bill Patrie, 800-944-1180 }\end{array}$ \\
\hline $\begin{array}{l}\text { DDROPS- } \\
\text { Decontamination, } \\
\text { Decommissioning, \& } \\
\text { Remediation Optimal } \\
\text { Positioning System }\end{array}$ & $\begin{array}{l}\text { Optimize cutting and } \\
\text { waste box packing } \\
\text { of debris }\end{array}$ & INEEL & $\begin{array}{l}\text { INEEL } \\
\text { Dick Meservey, 208-526-1834, rhm@inel.gov }\end{array}$ \\
\hline BROKK & $\begin{array}{l}\text { Remote controlled } \\
\text { demolition robot }\end{array}$ & INEEL & $\begin{array}{l}\text { BROKK North American Sales, } 144 \text { Village } \\
\text { Way, Monroe, WA 98272 } \\
\text { Bill Barraugh, 360-794-1277, porbb@aol.com }\end{array}$ \\
\hline $\begin{array}{l}\text { PICS_Personal Ice } \\
\text { Cooling System }\end{array}$ & $\begin{array}{l}\text { Light weight self } \\
\text { contained individual } \\
\text { cooling for workers }\end{array}$ & $\begin{array}{l}\text { INEEL, } \\
\text { FEMP, ANL-E }\end{array}$ & $\begin{array}{l}\text { Delta Temax Inc., } 320 \text { Boundary Rd., Pembroke, } \\
\text { Ontario, Canada KSA 6W5 } \\
\text { Kirk Dobbs, 613-735-3996 }\end{array}$ \\
\hline Oxy-Gasoline Torch & $\begin{array}{l}\text { Fast and inexpensive } \\
\text { cutting of carbon } \\
\text { steel }\end{array}$ & $\begin{array}{l}\text { INEEL, } \\
\text { FEMP, ANL-E }\end{array}$ & $\begin{array}{l}\text { Petrogen, } 3001 \text { Cutting Blvd., Richmond, CA } \\
94804 \\
\text { Milt Heft, 510-237-7274, petrogen.com }\end{array}$ \\
\hline Track-Mounted Shear & Mobile demolition & FEMP & $\begin{array}{l}\text { John Deere, Pemberton \& Tiger Mfg. } \\
\text { Marty Prochaska, 513-648-4089 }\end{array}$ \\
\hline Hand-Held Shear & $\begin{array}{l}\text { Self powered shear } \\
\text { for tight locations }\end{array}$ & FEMP & $\begin{array}{l}\text { Rescue Team Inc., P.O. Box } 1277 \text {, } \\
\text { Fredericksburg, VA, } 22402 \\
\text { Marco Wischatta, } \\
\text { Chris Klughardt, } 540-891-6600\end{array}$ \\
\hline
\end{tabular}


Table 2. Proposed new technologies and facilities.

\section{Technology Key}

1. Pipe Explorer

2. GammaCam

3. D\&D Remediation Optimal Planning System

4. BROKK with Scabbler, Hydraulic Shears, Grapple, and Hammer

5. Personal Ice Cooling System (PICS)

6. Oxy-Gasoline Torch

7. Track-Mounted Shear

8. Hand-Held Shears

\begin{tabular}{lll}
\hline \multicolumn{1}{c}{ Facility } & Site & Technologies \\
\hline TAN 616 & INEEL & $2,3,4,5,6$ \\
TRA Filter Pits & INEEL & 1 \\
CFA 691 & INEEL & 6 \\
Propane Storage Building 38A & FEMP & $5,6,7$ \\
Cylinder Filling Station 38B & FEMP & $5,6,7$ \\
Railroad Engine House 24B & FEMP & $5,6,7$ \\
Harshaw Digestion Fume Recovery 3F & FEMP & $5,6,7$ \\
Refrigeration Building 3G & FEMP & $5,6,7$ \\
Building 301 & ANL-E & 5,6 \\
\hline
\end{tabular}




\section{DESCRIPTION OF TECHNOLOGIES}

Following are descriptions of the technologies and brief discussions of how they will improve on the baseline performance in safety, radiation exposure, waste volume, schedule, and cost.

\section{Pipe Explorer}

The Pipe Explorer is deployed within piping systems by air pressure within plastic sleeving. It can deploy a video camera for interior pipe inspection, radiation detectors for characterizing pipe interiors, or an electronic transmitter to positively identify the location of a pipe. As the Pipe Explorer is withdrawn from the pipe, the plastic sleeving is also withdrawn and folded back over itself to contain all contamination. The device will inspect pipe interiors during INEEL's TRA Filter Pit (see Figure 8) D\&D operations. The device is significantly cheaper and safer than the conventional process of digging up sections of pipe to determine their location and then opening up the various sections to obtain samples for laboratory analysis as part of the characterization process. It also offers more accurate data about the pipe contents than sampling because it scans the entire length of pipe. This technology was successfully demonstrated at the Chicago CP-5 Large Scale Demonstration.

The Pipe Explorer (see Figures 9 and 10) improves safety and reduces risk because it positively identifies the location of all pipes and assesses their contents. It also identifies where unknown pipes may enter the system and cause unexpected problems during dismantlement of the facility. Using the Pipe Explorer is more cost effective than digging to locate pipes and then having to open them up to obtain information about their contents.

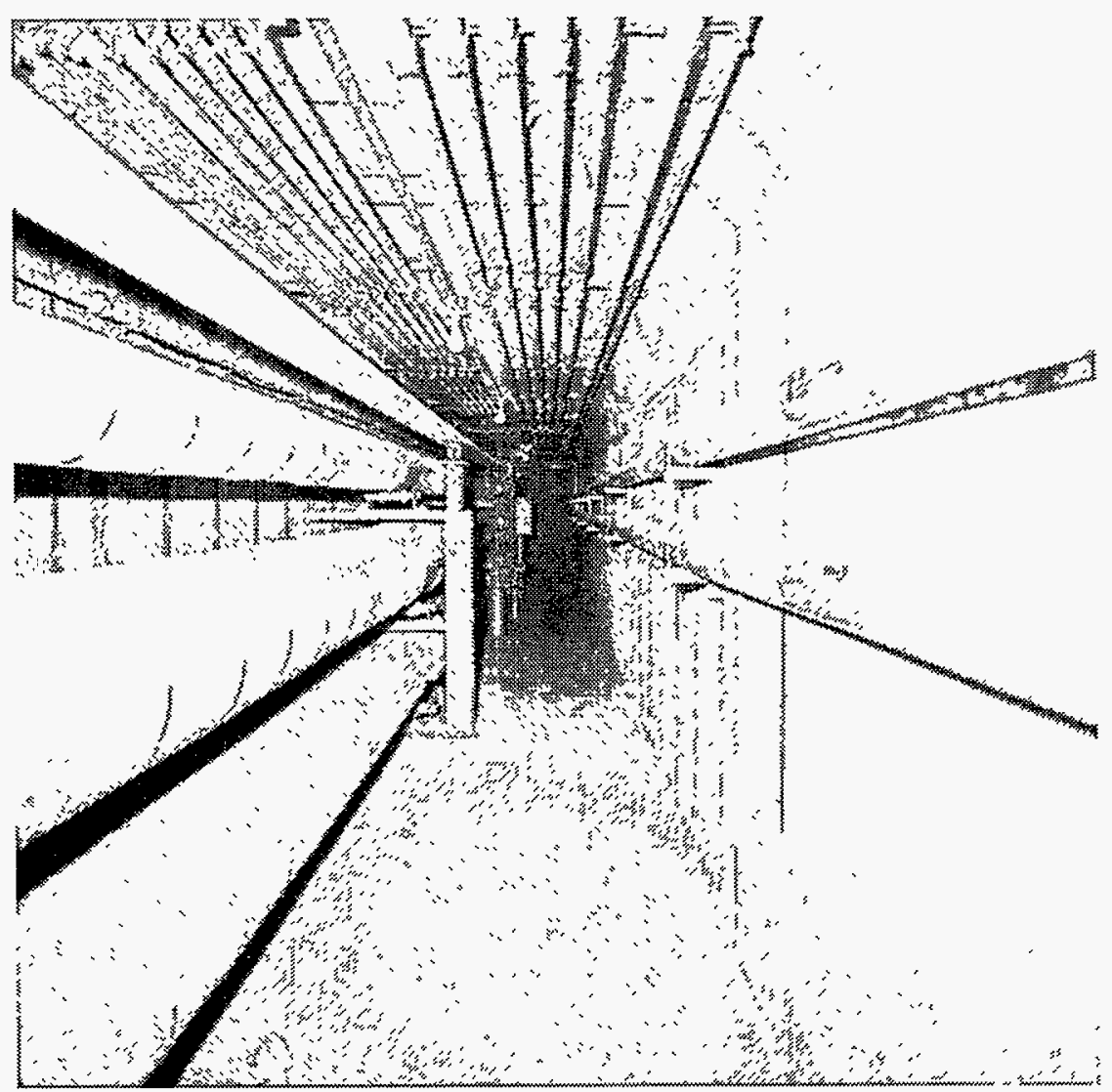

Figure 8. The Pipe Explorer will characterize piping at the INEEL TRA Filter Pits. 


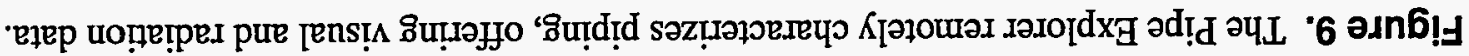

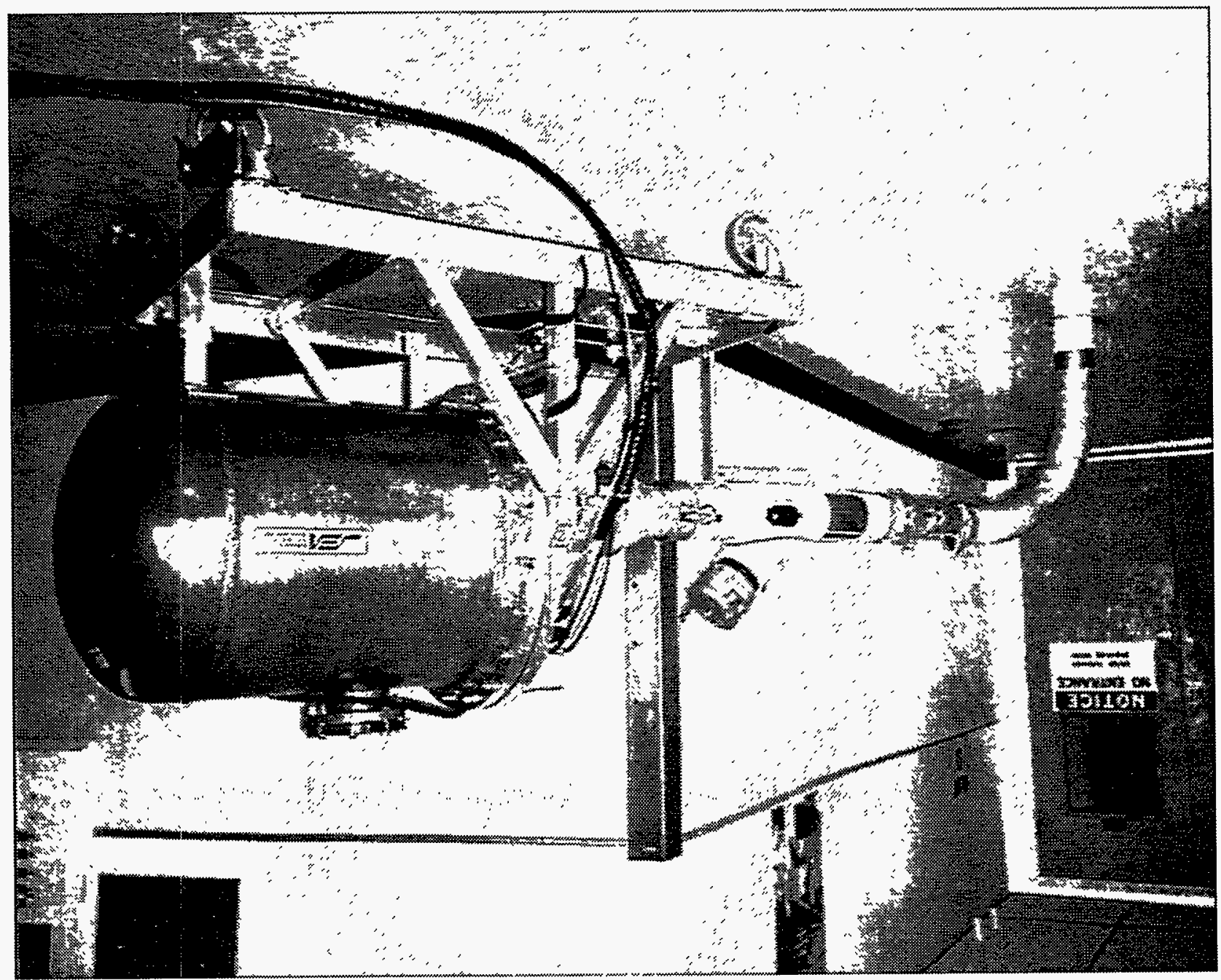




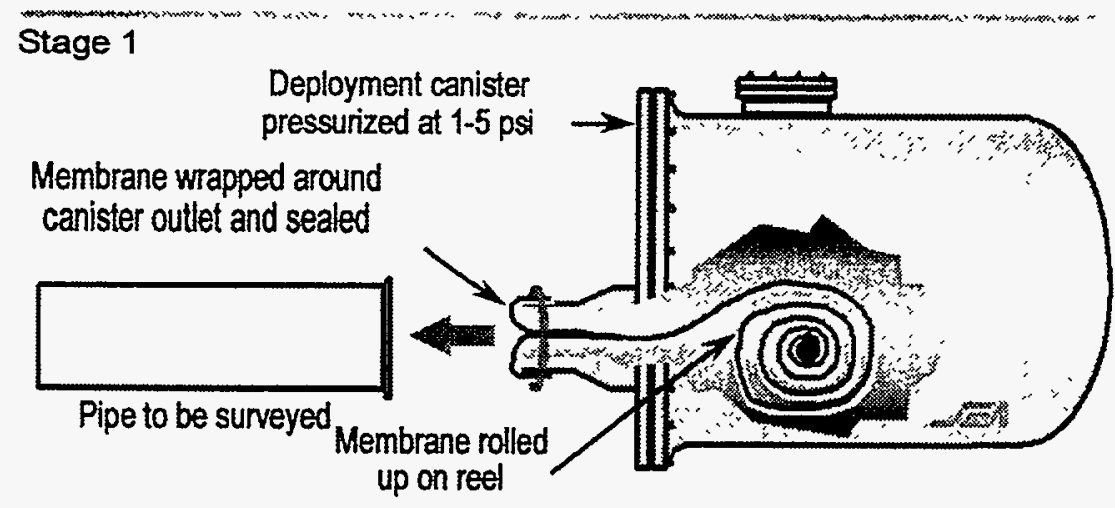

Stage 2
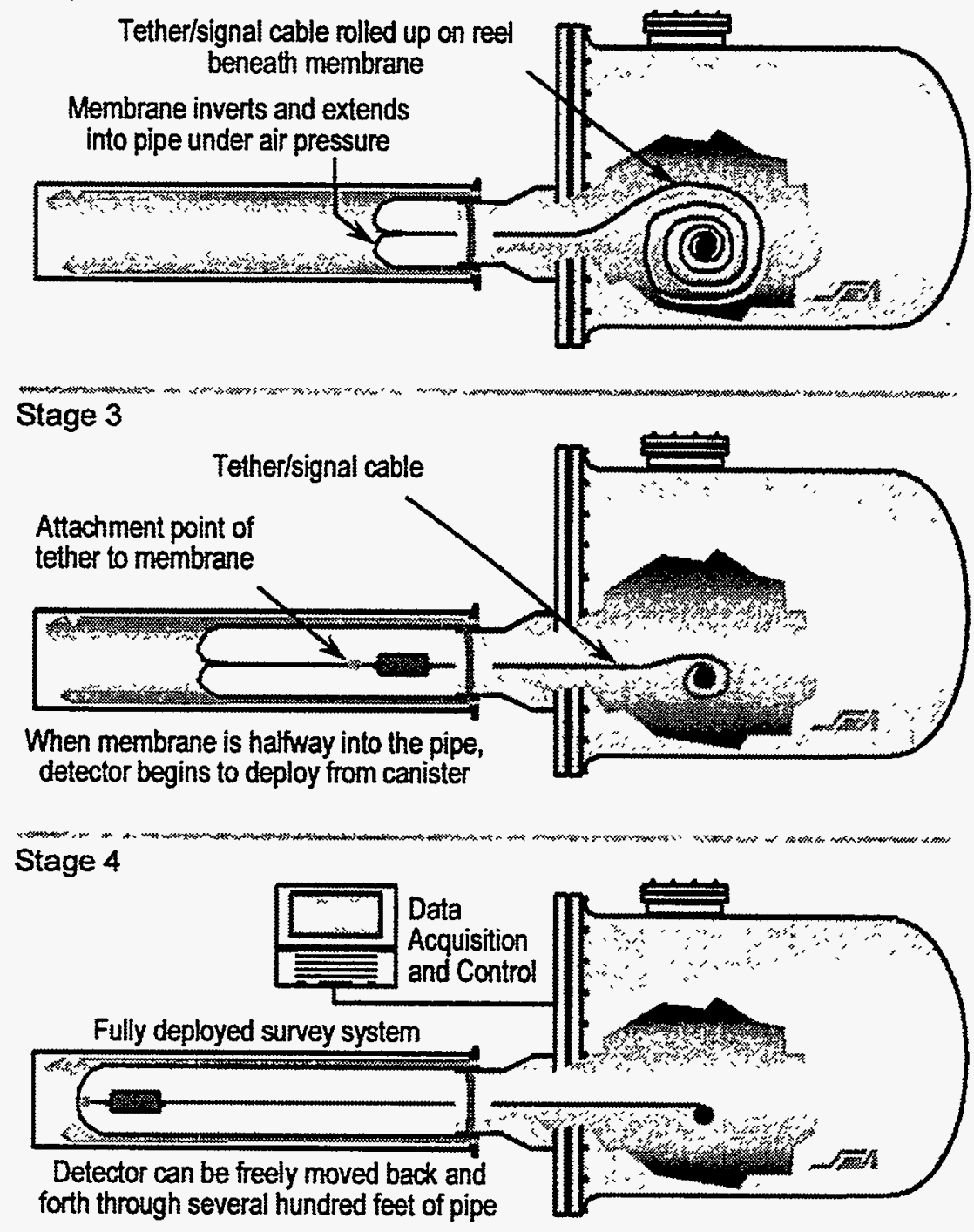

Figure 10. A protective membrane keeps the sensor clean during Pipe Explorer deployment. 


\section{GammaCam}

The GammaCam (see Figures 11 and 12), a gamma-ray sensitive camera, superimposes radioactive hot spot data on video images of the facility. The GammaCam performed well at the Chicago CP-5 and Fernald Large Scale Demonstration Projects. It was also tested under field conditions at the INEEL. Its strong feature is that it remotely and quickly identifies radioactive hot spots in a facility, significantly reducing radiation exposure to the workers.

The GammaCam will improve safety by decreasing the exposure workers get when they have to enter a facility and manually locate and measure hot spots. It will also greatly reduce the risk of workers being injured or contaminated while working in the facility because it can be operated from outside the contaminated area. Its use will reduce costs because less time and fewer workers are required to obtain the hot spot data than with the conventional/baseline process. Anticontamination clothing will not be needed for large groups of workers because they need not enter the highly contaminated areas.

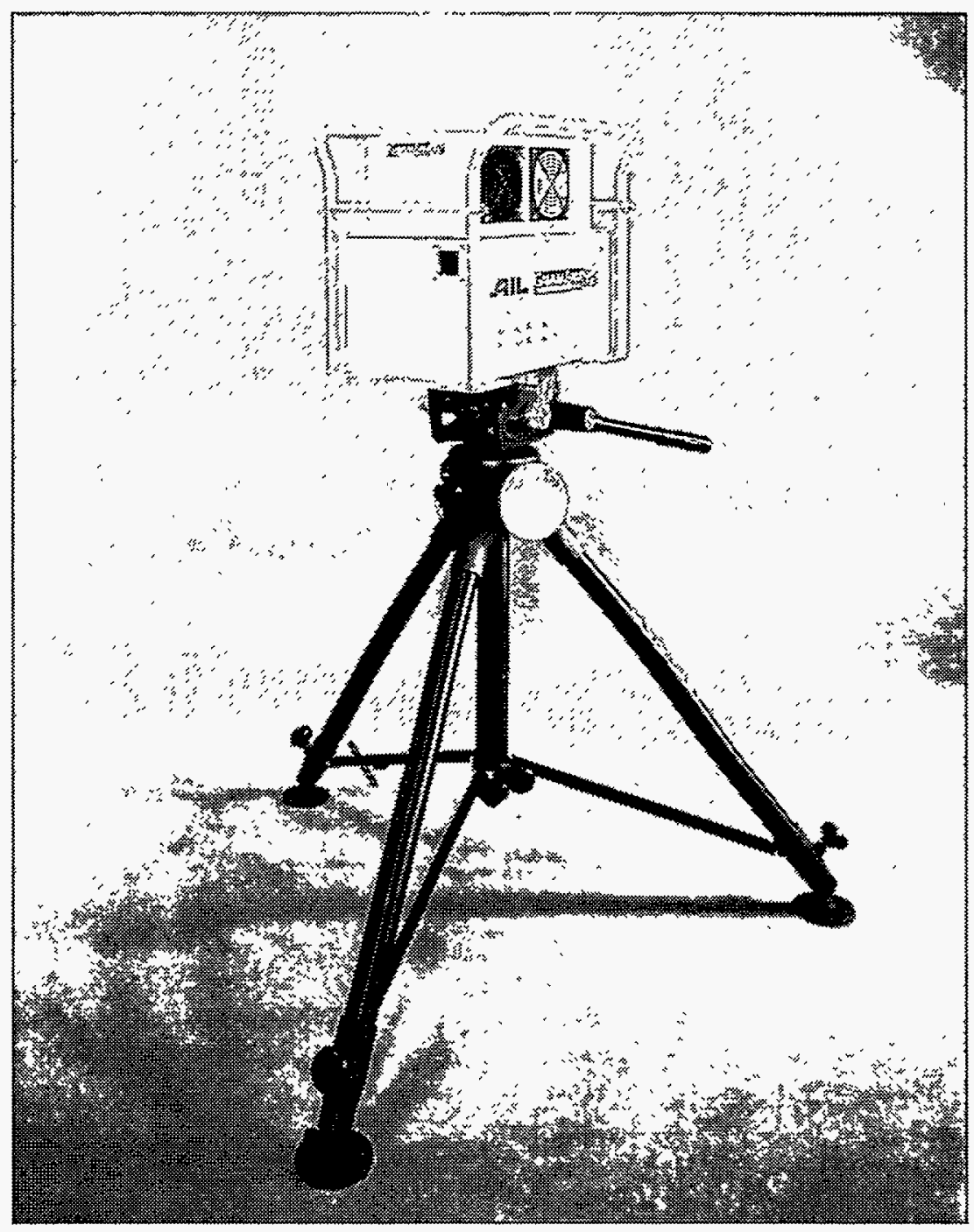

Figure 11. The GammaCam performs remote radiation surveys, reducing worker radiation exposure. 


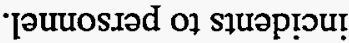

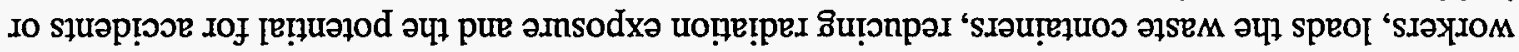

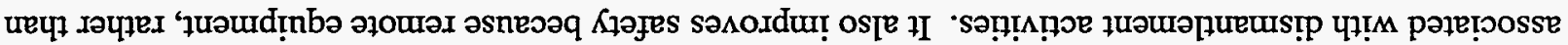

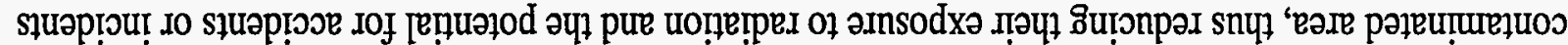

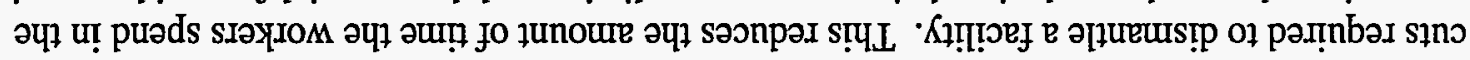

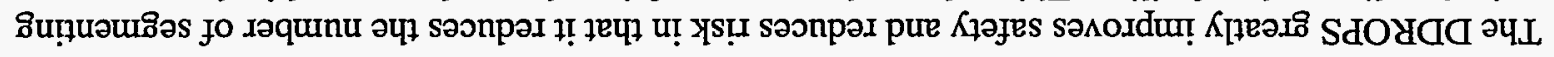

·psods!p Ioj jüs

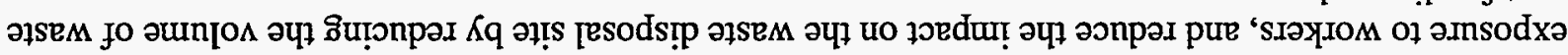

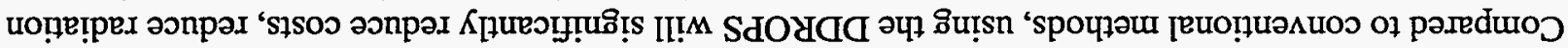

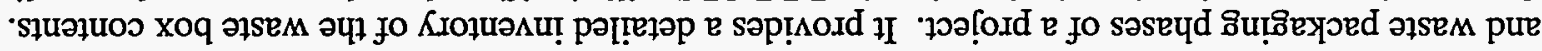

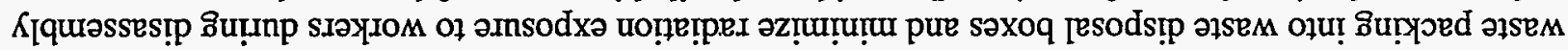

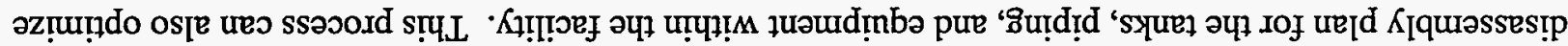

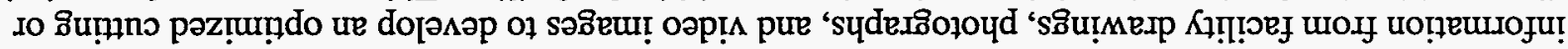

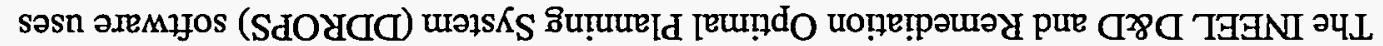

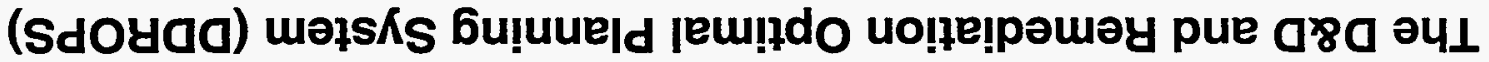

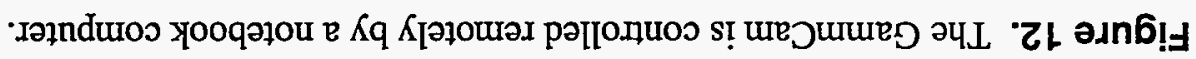

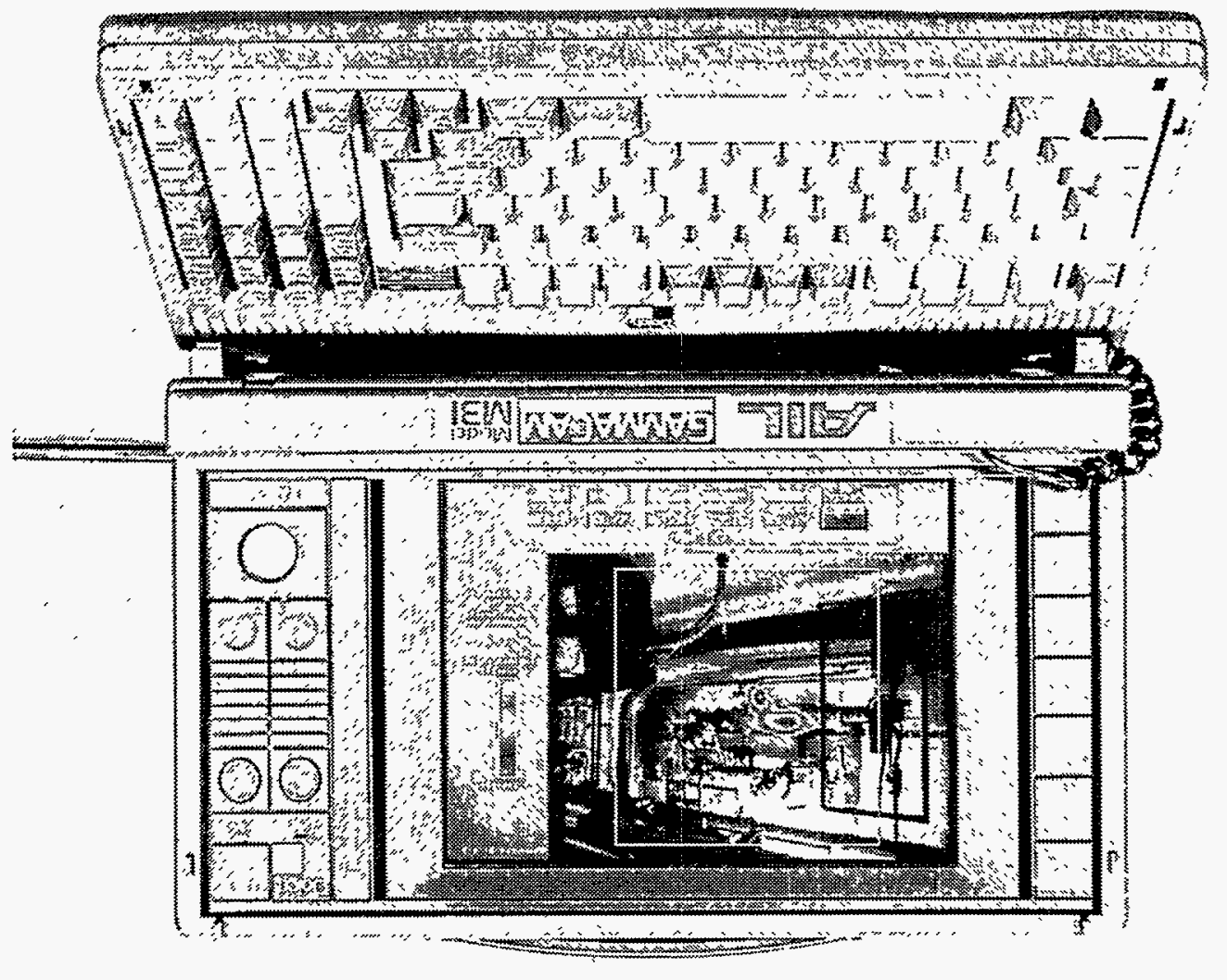




\section{BROKK Demolition Robot with Hydraulic Shear, Grapple, and Scabbler}

The BROKK (see Figure 13) robot has been successfully used on many D\&D projects, both in the United States and in many foreign countries. The BROKK has interchangeable end-effectors that can be used for a variety of tasks. The end effectors purchased include hydraulic sheer, grapple, scabbler, hammer, and bucket.

The BROKK robot with hydraulic shear end-effectors segments the smaller piping and equipment within a facility. The D\&D and Remediation Optimal Planning System (DDROPS) will determine the location of segmenting cuts, minimizing the number of cuts and maximizing the packing density in the waste boxes. The robot has been successfully used on many D\&D projects to segment piping and equipment. Using the grapple end-effector the machine can retrieve segmented items from a facility to further reduce radiation exposure to workers. Once the piping, tanks, and other equipment are removed from a facility, the walls and floors can be decontaminated remotely using a scabbler deployed by the BROKK.

The BROKK-deployed hydraulic shears and grapple offer significant advantages in cost and safety over baseline technologies. It quickly and efficiently cuts small piping without having workers near the material being segmented. This improves the radiological safety of the workers and reduces the risk of injury or accident. The BROKK equipment can remove the waste materials from the facility and move them to the waste staging area. The BROKK will later be used in conjunction with the DDROPS to load the waste containers.

Using the DDROPS waste packaging optimization process along with the remote-control capabilities of the BROKK equipment offers cost and safety advantages. Cost will be reduced because waste volume will be reduced, which will reduce the number of waste containers and reduce waste disposed at the waste disposal site. Safety will improve and risk will be reduced by remotely loading waste into the waste containers. This technology will virtually eliminate worker radiation exposure from this activity.

The remote scabbler (see Figure 14) deployed by the BROKK significantly reduces radiation exposure. Radiation exposure levels will be reduced both by removing workers from the area until the overall radiation fields are lower and by removing them from the area during times of high airborne contamination.

The BROKK can robotically deploy coatings, which is a safety advantage over manually deployed systems because it eliminates the need for workers in the area and it fixes contamination that otherwise may spread. Using coatings is safer than vacuuming the loose contamination because coatings are less likely to cause airborne contamination that could escape from the facilities. Using robotically deployed coatings would reduce the risk of contamination to workers and the risk of spreading loose contamination.

\section{Coatings}

The INEEL conducted a review of strippable coatings and polymeric barriers suitable for control of dispersible contamination during the TAN-616 Liquid Waste Treatment Facility D\&D effort. A primary project requirement was that the coating material be spray applied using a robotic vehicle and that coating removal could be accomplished with minimal worker risk. Vendor information on coating materials currently used in the commercial nuclear sector and the DOE complex and vendor and DOE user information collected by the Hemispheric Center for Environmental Technology at Florida International University was considered. 
One conclusion of the study is that application of a permanent or semipermanent barrier material may be appropriate for control of dispersible contamination. However, there is no experience to suggest that a strippable coating could be efficiently removed from vertical surfaces and complex shapes using a remote vehicle. Furthermore, coating materials containing chelating agents should be avoided because these compounds are unlikely to enhance the barrier material's ability to bind dispersible particles and may complicate subsequent waste treatment or material disposition activities. The two commercially available strippable coatings used within the DOE complex appear to include chelating agents in their formulation.

The INEEL will consider the use of the Polymeric Barrier System (PBS; Bartlett Services, Inc.), a semipermanent coating, and which is a current baseline technology used as a decontamination sealant at the Hanford site. Outstanding issues that must be resolved before deployment of a strippable coating or the Polymeric Barrier System during INEEL D\&D efforts include durability, flammability, and disposability of the applied product.

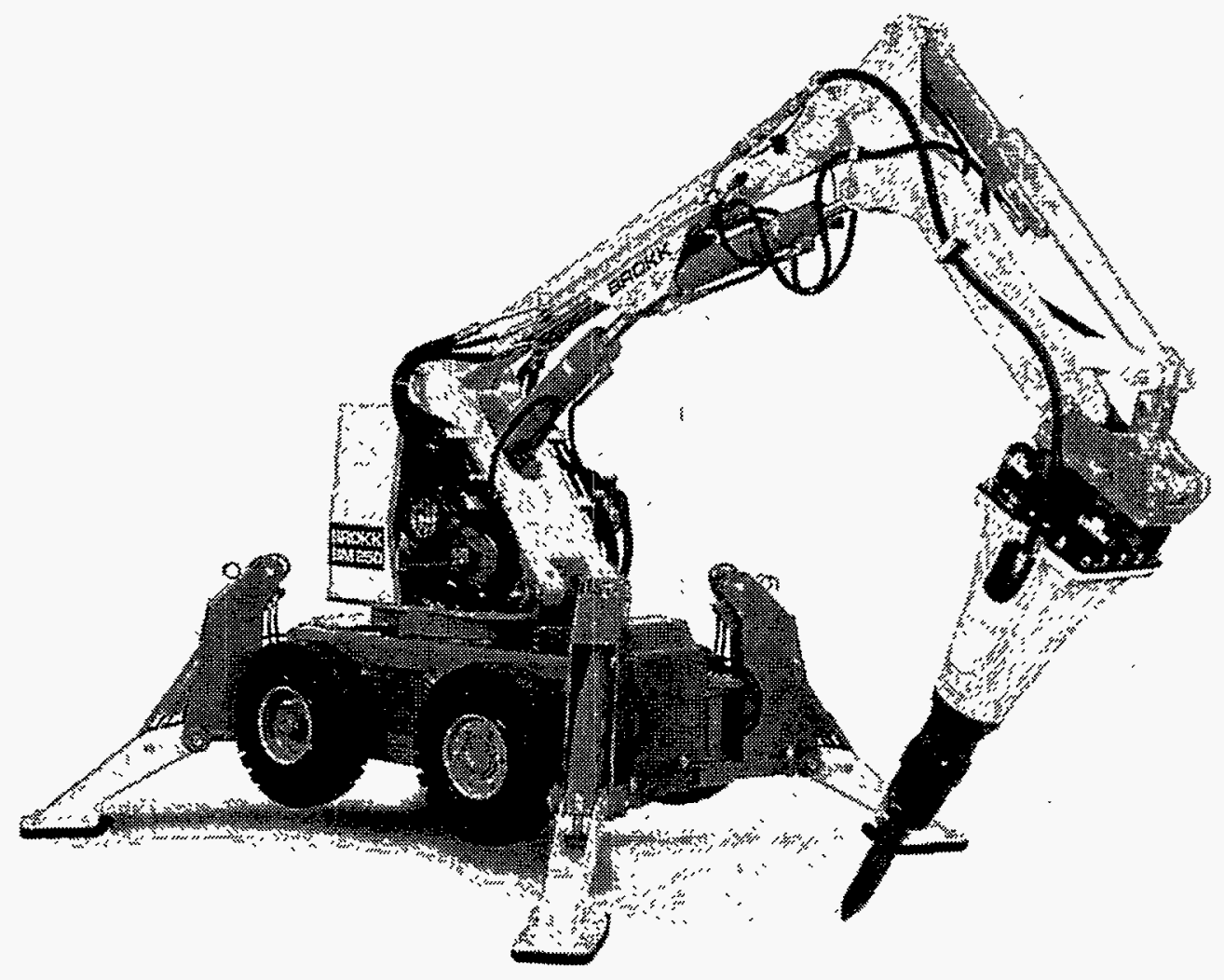

Figure 13. The BROKK 250 Demolition Robot uses a variety of end effectors to perform remote D\&D operations. 


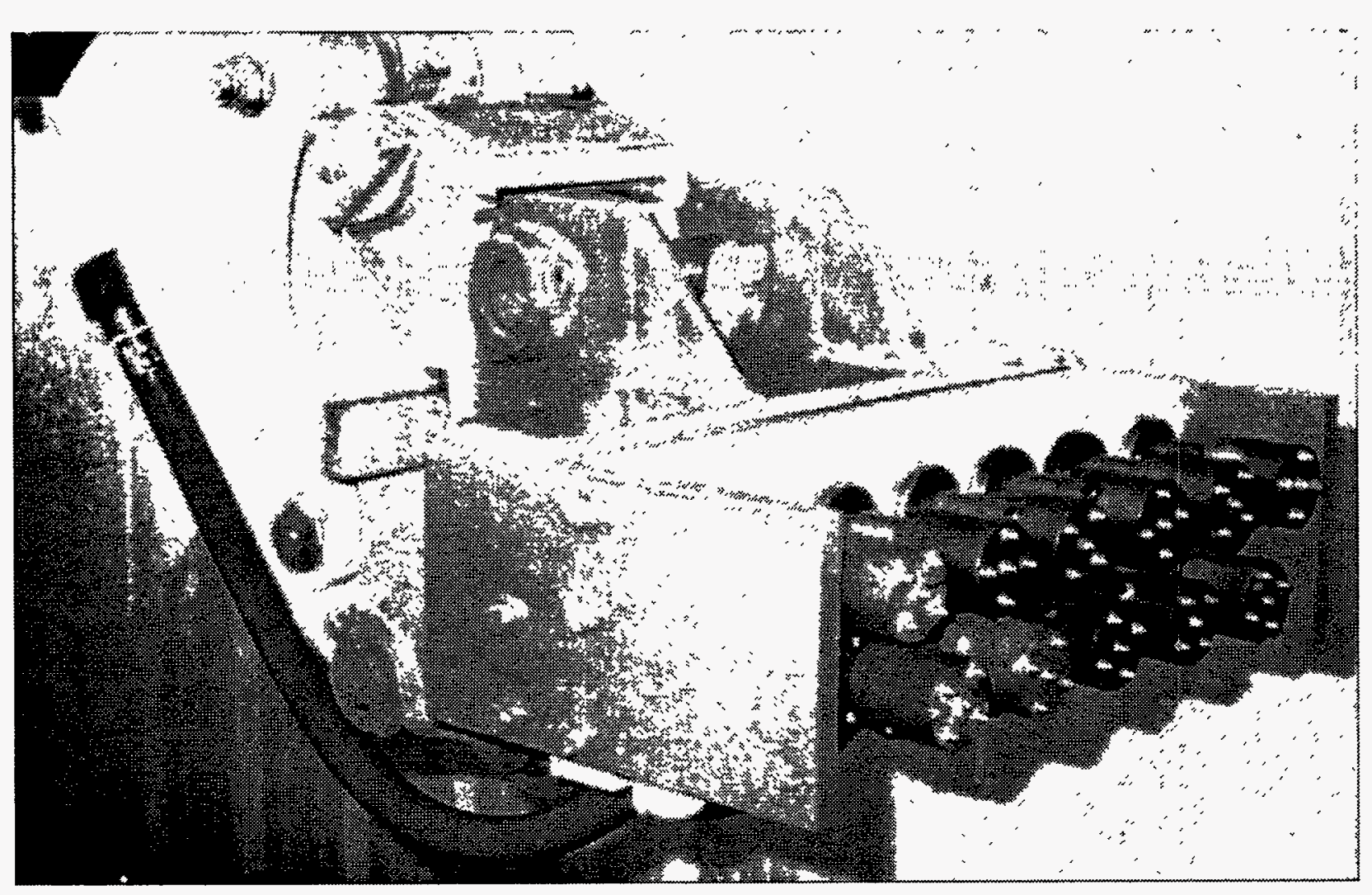

Figure 14. When operating the BROKK scabbler remotely, workers receive less radiation exposure than they would during hand-held scabbling operations.

\section{Personal Ice Cooling System}

The Personal Ice Cooling System (PICS) (see Figure 15) is a self-contained core body temperature control system that uses ordinary ice as a coolant and circulates cool water through tubing incorporated into durable, comfortable, body garments (pants, shirt and hood). Water is frozen in bottles that are worn outside/inside of anti-contamination clothing (anti-Cs) in a sealed, insulated bag, with a circulating pump attached to a support harness system. A rate-adjustable, battery-powered pump circulates the chilled water through the tubing in the suit. The adjustable pump allows the worker to control his/her temperature based upon his/her workload, unlike ice vests where the initial cooling is often extreme and uncomfortable. During demonstrations at FEMP, the PICS demonstrated its ability to maintain core-body temperature control and heat stress below health and safety threshold limits. During one demonstration, the PICS increased stay times four fold. Employee's pulse rates and core body temperatures were monitored at regular intervals as an added safety precaution.

The Personal Ice Cooling System will increase productivity and worker comfort. Safety will be improved by decreasing the potential for heat stress and by reducing the number of personal protective equipment changes needed for a job. During the Large Scale Technology Demonstration Project, worker response to the suits was very positive, indicating that they were more comfortable than when wearing the baseline cooling suits. 


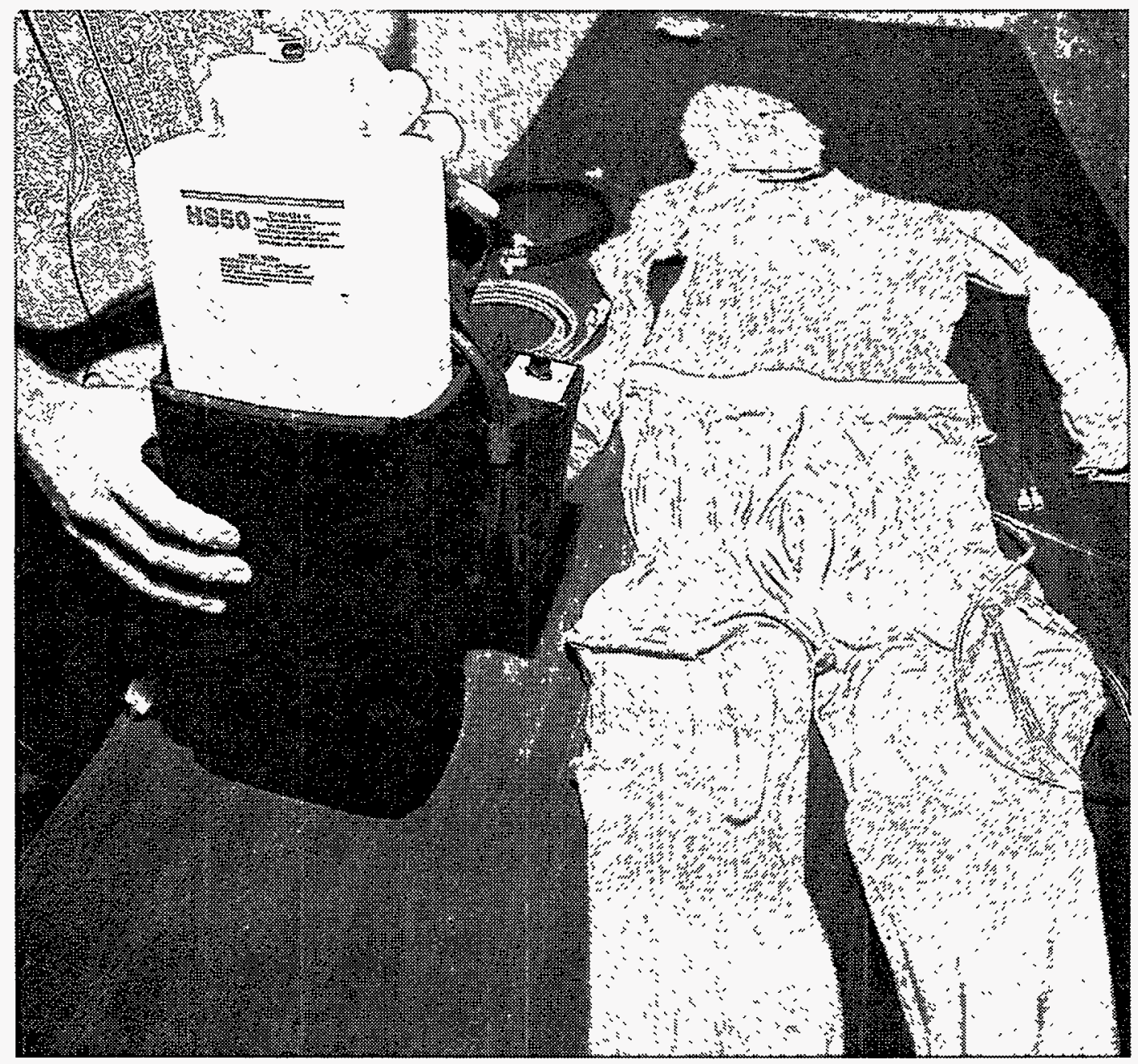

Figure 15. The Personal Ice Cool System keeps workers cool, extending stay times and increasing productivity.

\section{Oxy-Gasoline Torch}

The Oxy-Gasoline Torch (see Figures 16 and 17), successfully demonstrated at the Fernald Large Scale Demonstration Project, will cut or segment larger pipes, equipment, or structural components in a facility. Its safety and cutting efficiency are significant. It significantly improves safety performance by eliminating burning metal slag blowthrough. Backflash is prevented in the Oxy-Gasoline Torch because the gasoline is liquid all the way to the mixing tip. Other than the potential for molten-metal-started fires, which are common with other torch cutting equipment, risk is not as much of a factor. The Oxy-Gasoline Torch will replace the standard oxy-acetylene torch. On a 5.1-cm (2-in.) thick steel plate, the OxyGasoline Torch required 13 minutes to perform the cut; the acetylene torch required 27 minutes. Significant fuel savings were documented for the Oxy-Gasoline Torch. When cutting thick steel, approximately $\$ 3$ (2.5 gal) of gasoline lasted the full workday. For the same operation, $\$ 32$ of acetylene was required. 
'

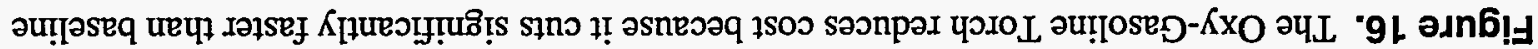

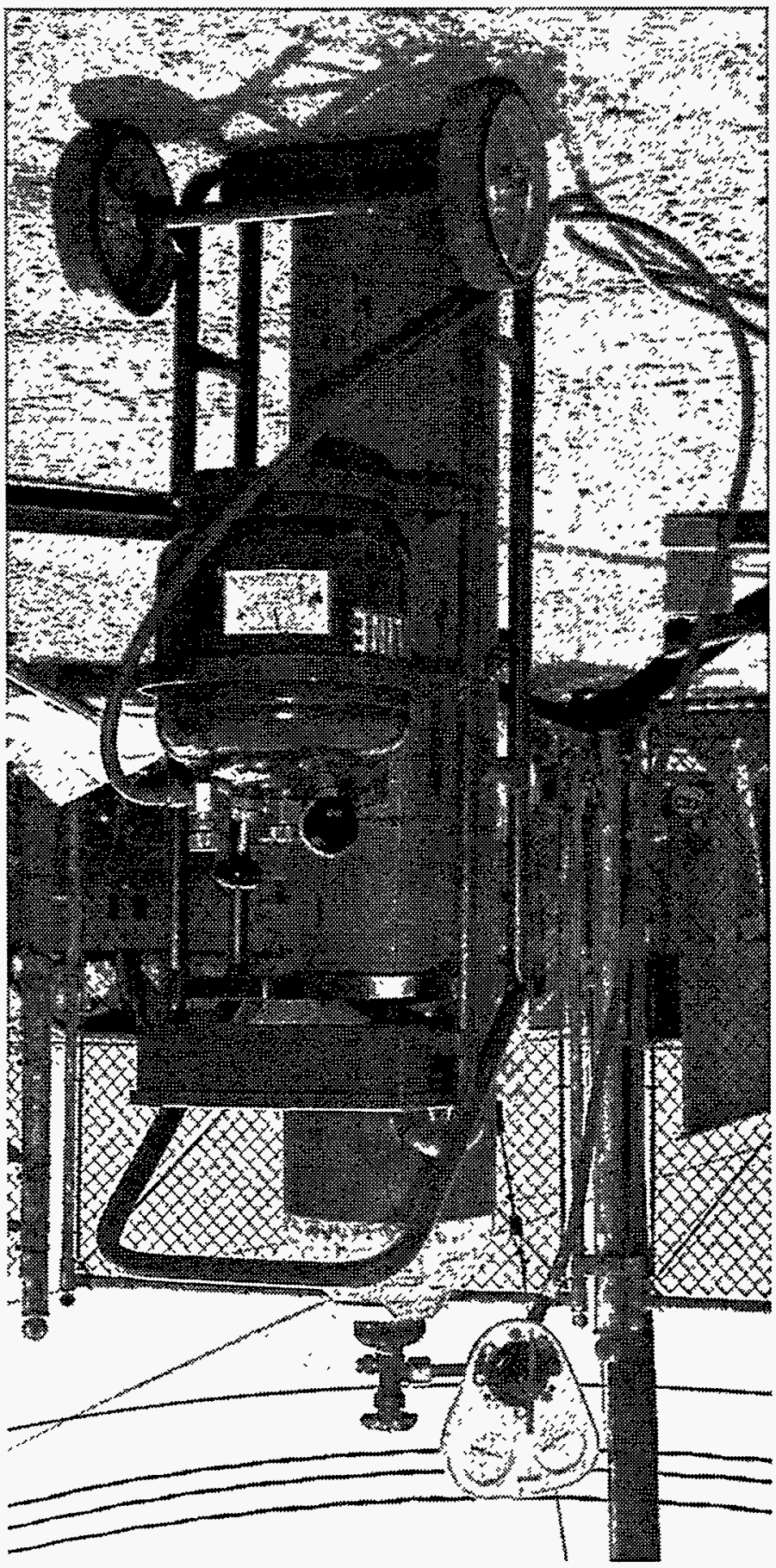




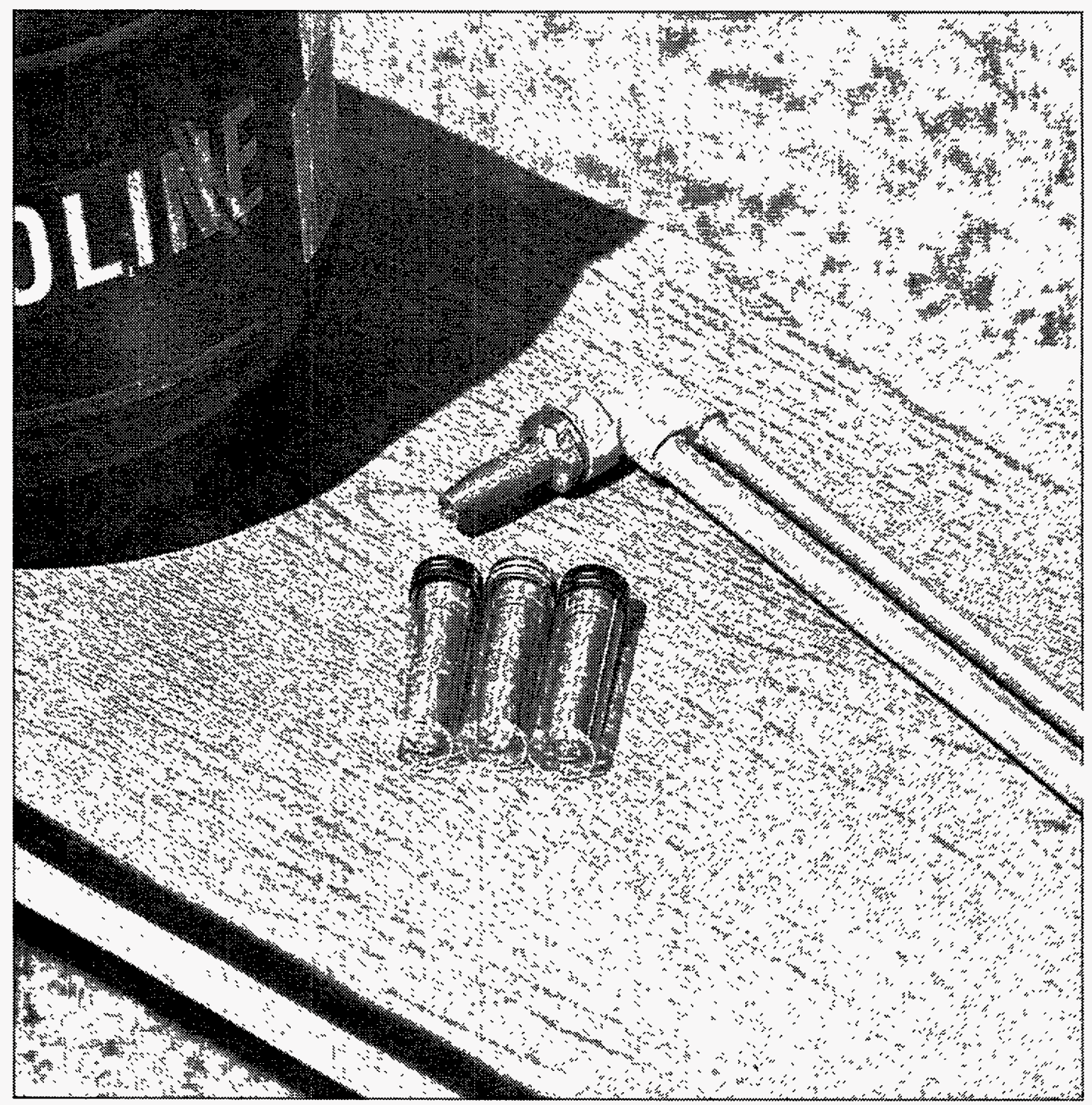

Figure 17. Backflash is prevented in the Oxy-Gasoline Torch because the gasoline is liquid all the way to the mixing tip. 


\section{Track-Mounted Shear/Crusher}

Using the remote-controlled Track-Mounted Shear (see Figure 18) will result in cost and schedule savings, as well as increased safety. It will increase productivity of both cutting and concrete removal operations by $25 \%$ over the baseline.

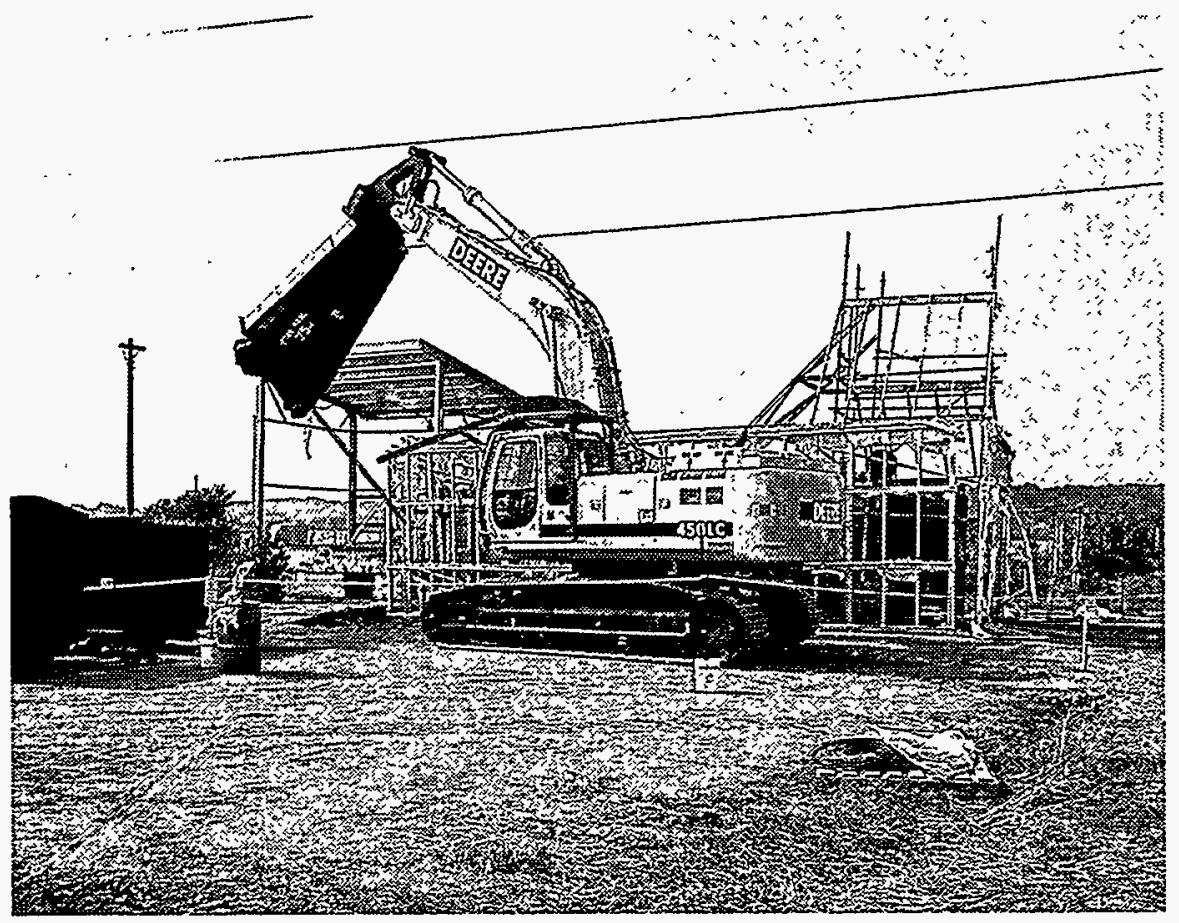

Figure 18. The Track-Mounted Shear reduced cost and exposure during D\&D operations at FEMP.

\section{Lucas Hand-Held Shears}

The Lucas Hand-Held Shears (see Figure 19) were used successfully in the Large Scale Demonstration to shear pipes up to $6.4 \mathrm{~cm}(2.5 \mathrm{in}$.) in diameter. These shears are portable, requiring no hydraulic or power lines, so they provide easier access to remote areas. In addition, they can cut pipes that are attached to walls without needing to loosen the pipe hangers. Both features should result in reduced schedules. Another feature of the shears is that they crimp piping up to $75 \%$ during cutting, so loose pipe contents are contained better than with conventional cutting methods. Both the portability nature and cutting method of the Hand-Held Shears should result in reduced radiation exposure.

On small pieces of piping and steel, the Hand-Held Shears will replace the baseline method of cutting, which is a saw or torch. The Hand-Held Shears will improve health, safety, and productivity. They perform cutting operations $20 \%$ faster than the baseline methods and generate little or no airborne contamination. 
-suoṭejədo

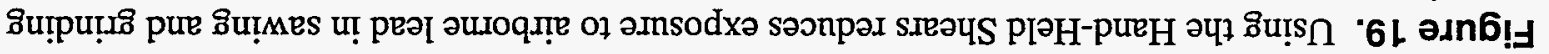

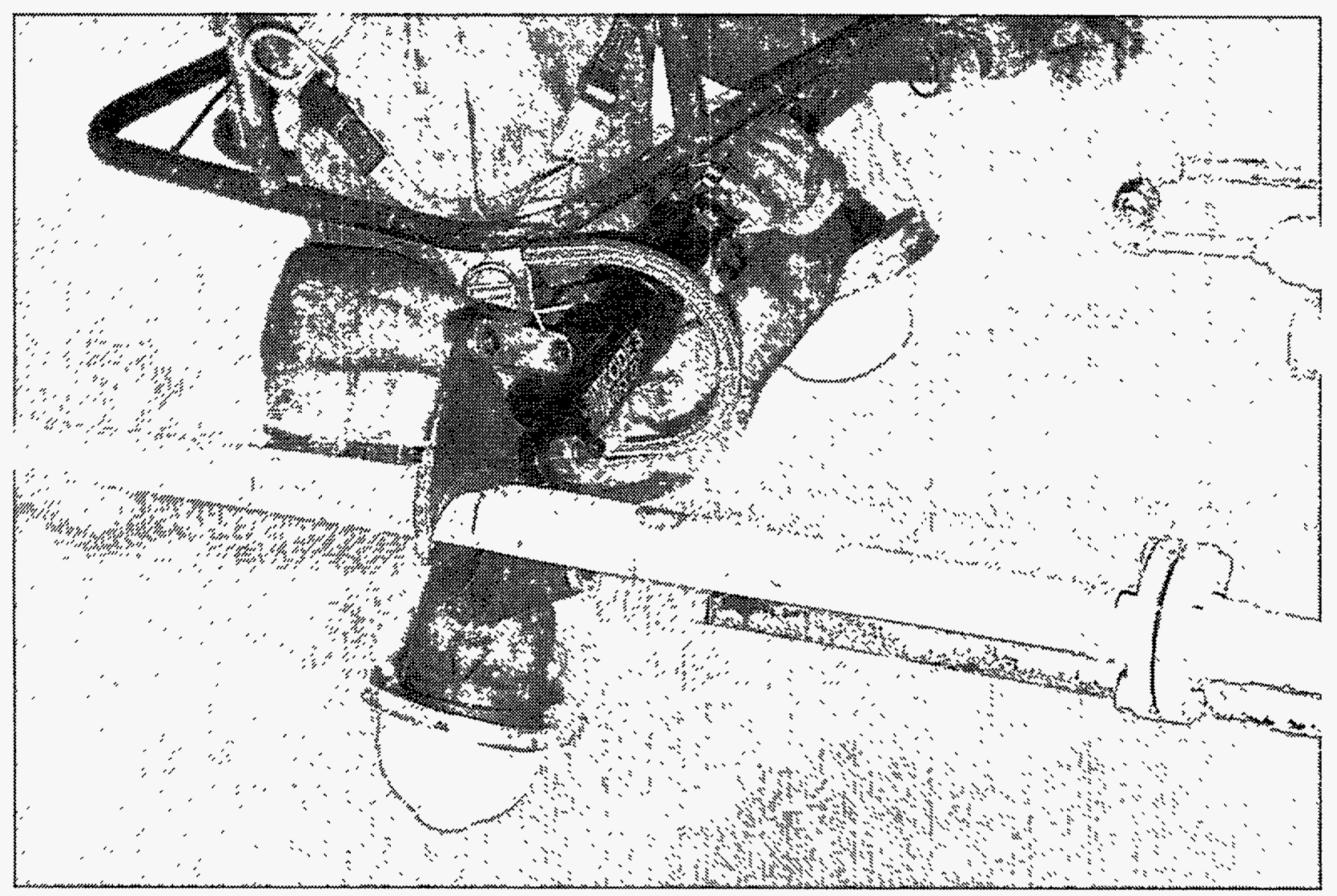




\section{DEPLOYMENT ACTIVITIES}

Deployment of these improved technologies is integrated among INEEL, FEMP, and ANL-E D\&D projects and is included in the ten-year plans for these sites. For maximum efficiency, once deployment is completed at one facility, the experience gained with the technology will be shared with the next facility ready to deploy the technology. This sharing will include active involvement by project and operational personnel to facilitate deployment. Technologies will first be deployed at the INEEL CFA-691, FEMP 38A, or ANL-E 301 facilities, then deployed to the next available D\&D facility. The need for these advanced technologies at other surplus facilities throughout all the DOE sites is clearly shown in individual long-range D\&D plans and the new ten-year plans. 


\section{BENEFITS FROM IMPROVED TECHNOLOGIES}

The following results are expected from replacement of the baseline technologies with identified improved technologies proposed for this project:

- Decreased costs

- $\quad$ Significantly reduced radiation exposure to workers

- Significantly reduced volume of radioactive waste disposed

- Improved safety environment for workers

- $\quad$ Adoption of these improved technologies for future applicable D\&D work.

Each of the technologies chosen for implementation and deployment are fully developed and have been successfully demonstrated in the Fernald, Hanford, or Chicago CP-5, D\&D Large Scale

Demonstration Projects, or are a commercially available technology proven in a commercial application. The purpose of this project is to identify where efficiencies can be made using these new technologies and to add these new technologies to the current baseline D\&D toolbox. Any cost savings realized from early and efficient D\&D of the facilities will be applied to the deployment of the technologies at additional facilities at the participating sites. This reinvestment of cost savings will result in mortgage reduction, D\&D project savings, and future D\&D operational savings. 


\section{PROJECT SCHEDULE}

The project milestones are presented in Table 3. Table 4 shows the ASTD ID\&D Project Schedule for the INEEL, FEMP, and ANL-E projects. Where possible, detailed schedule information is included. Detailed schedules for some projects are not currently available but will be supplied as they are developed.

Table 3. 1998 ASTD-ID\&D project milestones.

\begin{tabular}{|c|c|c|}
\hline & Milestone & Complete By \\
\hline A1 & $\begin{array}{l}\text { Update the Deployment Plan. The Deployment Plan is a living document and } \\
\text { will be updated periodically as information becomes available. }\end{array}$ & $4 / 30 / 98$ \\
\hline $\mathrm{C} 1$ & $\begin{array}{l}\text { Complete procurement actions and/or lease agreements and have the hardware or } \\
\text { technologies on site, or arrangements made for on site delivery based on the } \\
\text { D\&D schedule. }\end{array}$ & $9 / 30 / 98$ \\
\hline D1 & $\begin{array}{l}\text { Issue a Technology Evaluation/Recommendation/Deployment Report } \\
\text { documenting the results of the new and/or improved technologies used to } \\
\text { perform the FEMP D\&D work on buildings 3G, 3F, 24B, 38A, 38B at FEMP. }\end{array}$ & 9/30/98 \\
\hline E1 & $\begin{array}{l}\text { Complete procurement actions and/or lease agreements on capital equipment and } \\
\text { have the hardware or technologies on site, or arrangements made for on site } \\
\text { delivery based on the D\&D schedule. }\end{array}$ & 9/30/98 \\
\hline $\mathrm{F} 1$ & Complete training of personnel on operation of new technologies for FY-99. & $7 / 30 / 99$ \\
\hline $\mathrm{F} 2$ & $\begin{array}{l}\text { Issue a Technology Evaluation/Recommendation Fact Sheet for the initial } \\
\text { technologies implemented at the TAN-616 and IET facilities. }\end{array}$ & 9/30/99 \\
\hline F3 & $\begin{array}{l}\text { Host a media day during field activities to showcase technologies to potential } \\
\text { customers and media. }\end{array}$ & $3 / 30 / 00$ \\
\hline F4 & $\begin{array}{l}\text { Issue a Technology Evaluation/Recommendation Fact Sheet for each of the } \\
\text { remaining technologies implemented or deployed at the TAN- } 616 \text { facility. }\end{array}$ & $7 / 30 / 00$ \\
\hline F5 & Prepare and issue a final report for the Technical Deployment Initiative project & $9 / 30 / 00$ \\
\hline G1 & $\begin{array}{l}\text { Issue a Technology Evaluation/Recommendation Fact Sheet on each of the } \\
\text { technologies used in the implementation/deployment at ANL-E. }\end{array}$ & $6 / 30 / 99$ \\
\hline
\end{tabular}




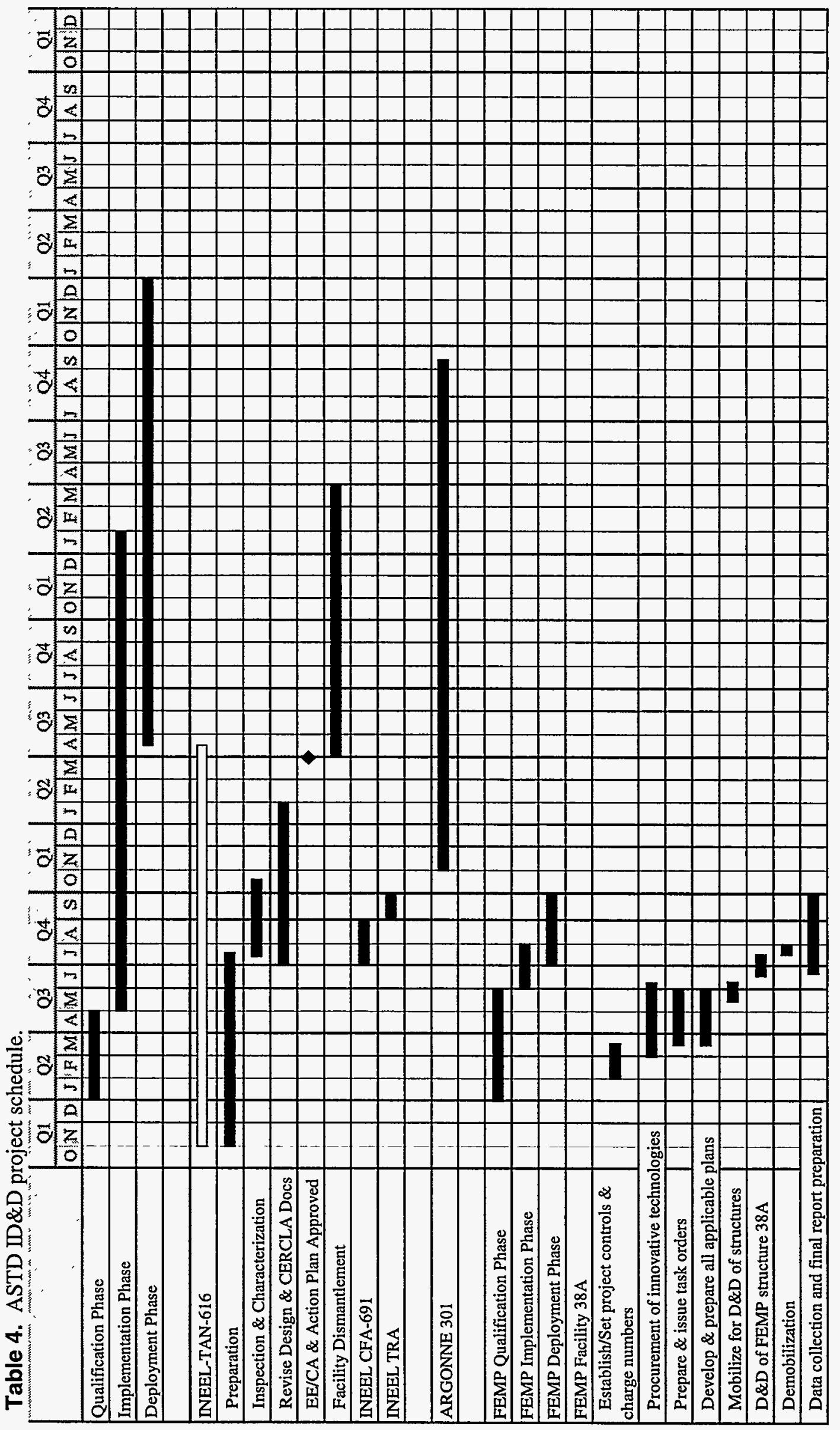




\section{INTERNET HOME PAGE}

Project activities and project information are available from the INEEL ASTD ID\&D Internet World Wide Web (Web) Sité at http://id.inel.gov/idd. The Home Page includes links to contacts, technologies, and documents. The ID\&D contacts are also listed in Table 5.

The World Wide Web (Web) Site is one of the many communication tools. Each site is developing a homepage to highlight accomplishments and to provide an efficient pathway to share pictures and other data. All of the homepages have links to each other and the largescale demonstrations. The homepage at INEEL will have a protected section which is accessible only to project personnel and will be used to share internal reports and documents.

The ASTD ID\&D Web Site and links to other sites (see Table 6) facilitate communications of the geographically dispersed members of the team, DOE, and others with public access to project information via the Internet and World Wide Web. This communication tool uses both Internet/Web and proprietary information protocols to share information and provide security with multiple access privilege levels.

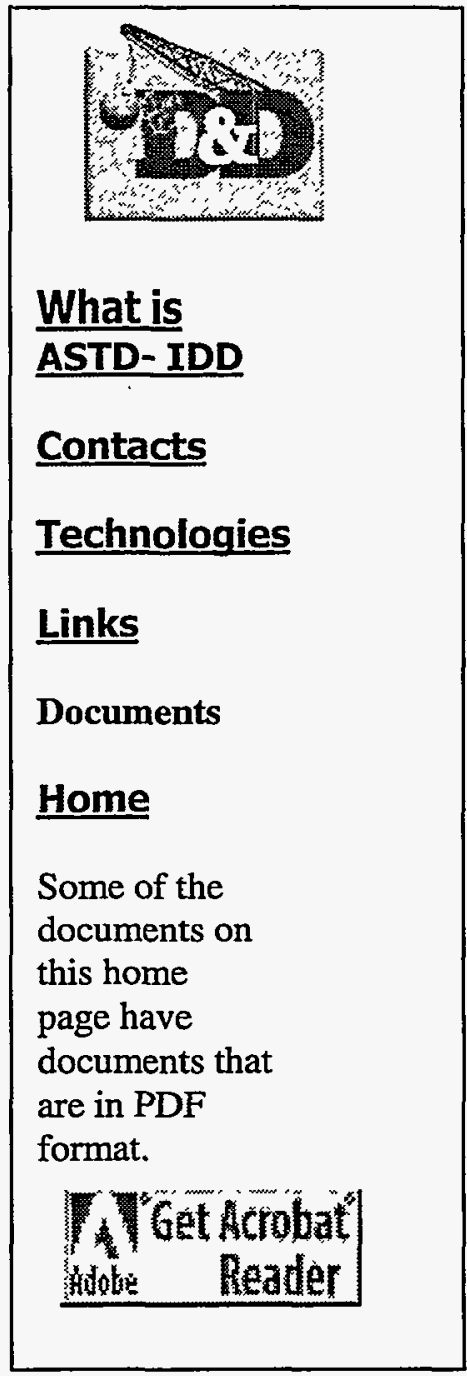

Table 5. ID\&D contacts.

\begin{tabular}{llcl}
\hline Location & \multicolumn{1}{c}{ Person } & \multicolumn{1}{c}{ Phone } & \multicolumn{1}{c}{ E-Mail } \\
\hline FETC & Harold Shoemaker & $304-285-4715$ & Hshoem@fetc.doe.gov \\
DOE-ID & Jim Wade & $208-526-6876$ & Wadejr@inel.gov \\
INEEL & Dick Meservey & $208-526-1834$ & rhm@inel.gov \\
& Ann Marie Smith & $208-526-6877$ & aqs@inel.gov \\
FEMP & Larry Stebbins & $513-648-4785$ & Lawrence.stebbins@fernald.gov \\
& Marty Prochaska & $513-648-4089$ & marty.prochaska@fernald.gov \\
ANL-E & Charles Fellhauer & $630-252-9569$ & Cfellhauer@anl.gov \\
\hline
\end{tabular}

Table 6. Internet addresses.

INEEL

http://www.id.inel.gov/idd/

Flour Daniel Fernald http://www.fernald.gov

FETC

http://www.fetc.doe.gov/ 


\section{INEEL ACCOMPLISHMENTS}

The Integrated Decommissioning and Decontamination Project was initiated in February of FY-98. Progress was made in identifying technologies, procuring equipment, training personnel, deploying technologies, and building the inter-site team.

Working with an operations team, the most successful technologies from large scale demonstrations and private industry were reviewed for their applicability to D\&D of facilities at the INEEL. The technologies selected to be used in this deployment are the BROKK Demolition Robot, PICS, Oxy-Gas Torch, DDROPS, GammaCam, and Pipe Explorer. Three technologies were procured: the Oxy-Gas Torch, the BROKK BM-250 Demolition Robot, and the Personal Ice Cooling System. A subcontract was issued to Science and Engineering Associates to characterize pipes near the TRA filter pits using the Pipe Explorer.

An evaluation of strippable and polymeric barriers that could be deployed remotely with the BROKK Demolition Robot to control dispersible contamination was completed. Numerous coatings were evaluated based on vendor data, Florida International University (FIU) testing data, previous INEEL evaluations, and literature data. One conclusion was that strippable coatings may be difficult to remove from complex structures and vertical surfaces using a remote vehicle. Using a semipermanent material such as Bartlett Services, Inc.'s Polymeric Barrier System is recommended to control dispersible contamination.

Deployment of the Oxy-Gas Torch was initiated at the CFA-691 building where it was used to cut rebar; this deployment will continue into FY-99 when heavier structural steel will also be cut. The Oxy-Gas Torch will also be deployed at TAN-616 during FY-99. The initial results with the torch are very encouraging. The learning curve for operators is very short and operators have commented on how much quicker the Oxy-Gas Torch cuts. They believe the torch is better ergonomically in tight quarters than the acetylene torch. The Oxy-Gas Torch provides 100\% oxidation, which means that melted material is blown through rather than remaining in the cut. This eliminates re-cutting to remove slag and increases safety because less molten metal (slag) is dropped from the cut near the workers.

The BROKK BM-250 demolition robot and associated end effectors (scabbler, shear, hammer, and grapple) were received. The BROKK is scheduled for deployment at buildings CFA-691 and TAN-616 during FY-99. In preparation for this work, operational testing and hands-on operation and maintenance training for the BROKK was completed in FY-98. Operator response to the training was positive.

The GammaCam will be deployed at TAN-616 in FY-99 where a large amount of loose contamination exists. An enclosure was designed and built for the GammaCam to prevent contamination of the machine during deployment.

The Personal Ice Cooling Systems have been received and operator training will be conducted in FY-99.

Within the INEEL, the ASTD has helped form the intra-site team by breaking down barriers to using new technologies. Numerous suggestions for additional deployment opportunities for the BROKK and Oxy-Gas Torch have been received from Operations.

INEEL and Fernald formed a strong team in FY-98. ANL-E has also participated in this team and will take a more active role in FY-99 as their work develops. A joint presentation and booth at Spectrum 98 in Denver, Colorado, was well received and generated a lot of interest from technology vendors and other sites. 


\section{FEMP ACCOMPLISHMENTS}

The Integrated Decommissioning and Decontamination Project activities at FEMP included equipment procurement, technology deployment, facility decontamination and decommissioning, and inter-site team building.

Four technologies were deployed and a total of five facilities were decommissioned.

The five facilities used for the deployments were (1) the Propane Storage Shelter (38A), (2) the Cylinder Filling Station (38B), (3) the Railroad Engine House (24B), (4) the Harshaw Digestion Fume Recovery Building (3F), and (5) the Refrigeration Building (3G). The deployments went more quickly than planned, in large part due to the effectiveness of the deployed ASTD technologies. Substantial savings were also realized in the area of cost; initial estimates indicate the deployed technologies saved approximately $\$ 14,344$ for the first three facilities decommissioned.

Four technologies were deployed: (1) the Hand-Held Shear, (2) the Track-Mounted Shear, (3) the Personal Ice Cooling System cool suits, and (4) the Oxy-Gasoline Torch.

The Hand-Held Shear was very effective for light duty (5.1-cm [2-in.] diameter or less) pipe cutting. This shear has a self contained power supply and reaches into corners that other cutting tools have difficulty accessing. Overall, the Hand-Held Shear cut about $20 \%$ faster than other cutting techniques for light cutting. The shearing action minimizes the amount of paint chipped from pipes and so minimizes lead exposure for workers.

The hot humid summer weather at FEMP provided an excellent test for the Personal Ice Cooling System cool suits; the suits functioned beautifully. The payback time for these suits can be as little as 9 hours when the ambient temperature rises above $85^{\circ} \mathrm{F}$. These suits increase the productivity and safety of the workers, which translates into schedule and cost savings for the project.

The Oxy-Gasoline Torch was very successful. It cut up to $65 \%$ faster than the oxy-acetylene torch commonly used. The gasoline fuel is significantly cheaper than the acetylene. The Oxy-Gasoline Torch is considered safer because it generates less slag than conventional torches and because the fuel stays in a liquid phase longer. The net result is safety improvement with cost and schedule savings.

FEMP and INEEL have worked well together and formed a strong team in FY-98. A joint presentation and booth presented at Spectrum 98 in Denver, Colorado, was well received and generated a lot of interest from technology vendors and other sites. 


\title{
BIBLIOGRAPHY
}

\author{
A. M. Smith, G. E. Matthern, R. H. Meservey, M. J. Prochaska, R. W. Rose, and L. L. Whitmill, \\ Deployment Plan for Integrated Decontamination and Decommissioning, INEEL/INT-98-00437. \\ DOE-ID, Decommissioning Handbook, DOE/EM-0142P, March 1994
}




\section{Appendix A}

Communications Plan for the Integrated Decontamination and Decommissioning Project in the Accelerated Site Technology Deployment Program

September 1998

Gretchen E. Matthern 


\section{Appendix A}

\section{Communications Plan for the Integrated Decontamination and Decommissioning Project in the Accelerated Site Technology Deployment Program}

\section{PURPOSE}

The Integrated Decontamination and Decommissioning project for the Accelerated Site Technology Deployment (ASTD) program includes three DOE sites (INEEL, Fernald, and ANL-E) in its activities. Success of this project requires effective communication among the three laboratory participants and other DOE sites, industry, and the public. This plan describes the specific communications activities planned, identifies the target audience for each of the activities, and presents a schedule for completion of those activities.

\section{OBJECTIVES}

A. Facilitate efficient and effective use of project resources among the three sites participating in this project.

B. Simplify deployment of innovative technologies to other DOE sites.

C. Share technologies and practical experience with other DOE sites, industry, and the public.

D. Provide performance data to stakeholders to assist in baseline revision and decision making.

E. Improve stakeholder awareness of innovative technologies that are available for decontamination and decommissioning tasks.

\section{SCOPE}

This plan includes the primary communication activities of INEEL, Fernald, and ANL-E. The activities are in two groups: internal and external communications. Internal communications cover project details such as scope, schedule, and budget which are not generally released to the public, and other information that is primarily pertinent to internal DOE customers. All project reports are included in the internal group because they are produced for internal customers even though most of the reports will be published as external reports.

\section{POINTS OF CONTACT}

The points of contact for the overall project are Dick Meservey (208-526-1834, rhm@inel.gov) and Kevin Kostelnik (208-526-9642, kvk@inel.gov). The points of contact for each of the participating sites are:

INEEL

Ann Marie Smith 208-526-6877, aqs@inel.gov

Gretchen Matthern 208-526-8747, gtn@inel.gov 
Fernald

Marty Prochaska

513-648-4089, marty.prochaska@fernald.gov

ANL-E

Charles Fellhauer

630-252-9569, Cfellhauer@anl.gov

\section{INTERNAL COMMUNICATIONS}

The following annotated outline of the primary internal communications activities for the project presents the participants and benefits of each task

\section{A. Project Status}

1. Weekly conference call-This call is organized by INEEL to provide a weekly update and discussion opportunity for project personnel. Contractor and DOE personnel from INEEL, Fernald, ANL-E, and FETC are invited to participate.

2. Monthly report-INEEL submits a monthly status report is compiled from individual reports prepared by INEEL, Fernald and ANL-E as appropriate. This report is available on the Project Tracking System.

3. Mid-year meeting-This meeting provides FETC a review of project progress, accomplishments, and issues. In FY-98 the review was prepared and presented by INEEL and Fernald as a team. In FY-99 the review will be prepared and presented by INEEL and ANL-E as a team.

4. Informal-Much of the teamwork is built on spontaneous communication by phone call, email, and fax.

\section{B. Personnel Exchange}

1. Operators-Members of the field teams at INEEL, Fernald, and ANL-E will visit each other's sites to participate in deployments. This exchange of personnel will improve crosssite communications and reduce the learning curve for the second site deployment of a technology.

2. Team Leads-Project personnel from INEEL, Fernald, and ANL-E will visit each other's sites to observe technologies during deployment. This exchange of personnel will increase cross-site communications and help personnel quickly evaluate technologies for use at their own sites.

\section{Project Plans}

1. Technical Task Plan-The TTP serves as a proposal and then formal agreement as to the scope, schedule, and budget for current and future fiscal year activities. INEEL prepares and maintains the control copy of this plan; the details of the plan are provided by the appropriate participant (INEEL, Fernald, ANL-E). 
2. Deployment Plan-This document presents a synopsis of the objectives, scope, schedule, and budget for the life cycle of the project. INEEL prepares and maintains the control copy of this plan, the details of the plan are provided by the appropriate participant (INEEL, Fernald, ANL-E).

\section{Project Reports}

1. Year end report-This report summarizes the activities of the current fiscal year. INEEL prepares this report with contributions from Fernald and ANL-E.

2. Technology evaluation reports-This 2-page report details information on the performance (in terms of cost, schedule, safety, and waste management) of specific technologies after they are implemented or deployed at a specific site. These reports are prepared by the site hosting the implementation/deployment.

\section{EXTERNAL COMMUNICATIONS}

\section{Conferences}

1. Spectrum 98-This international conference is sponsored by the American Nuclear Society and is held in Denver, Colorado, September 13-18, 1998. A joint booth display will be provided by INEEL, Fernald, and ANL-E. In addition, INEEL and Fernald will be presenting a paper on the deployment activities.

2. Waste Management 99-This international conference is organized by Waste Management Symposia, Inc. and is held in Tuscon, Arizona, February 28-March 4, 1999. INEEL will submit a paper discussing the experienced gained with the Accelerated Site Technology Deployments and Large Scale Decontamination and Decommissioning Program projects at the site.

B. News Media Awareness Day-A show-and-tell day will be organized at INEEL to showcase the technologies deployed at the site. Video and still photographs of the actual work will be available as will the actual pieces of equipment (when feasible). Technologies such as the BROKK, and cool suits will be available for use under simulated conditions. Project personnel will be available to scrutinize the project and to answer questions.

C. Trade Publications-Opportunities will be sought to publish articles in several industry publications. Project personnel will work with the INEEL public relations team to identify interview opportunities and to develop appropriate copy and photographic materials.

D. Video-All of the sites are documenting their activities with video and still photography to support report, publication, and media needs. INEEL will produce a summary video of all of the technologies implemented or deployed at INEEL, Fernald, and ANL-E.

E. Homepage-Each site is developing a homepage to highlight accomplishments and to provide an efficient pathway to share pictures and other data. All of the homepages have links to each other and the large-scale demonstrations. The homepage at INEEL will have a protected section accessible only to project personnel and will be used to share internal reports and documents. 